AISI/DOE Technology Roadmap Program

\author{
Final Report
}

\title{
A Feasibility Study for Recycling Used Automotive Oil Filters in a Blast Furnace
}

\author{
by
}

Ralph M. Smailer,

Gregory L. Dressel, and

Jennifer Hsu Hill

January 2002

Work Performed under Cooperative Agreement

No. DE-FC07-97ID13554

Prepared for

U.S. Department of Energy

Prepared by

American Iron and Steel Institute

Technology Roadmap Program Office

Pittsburgh, PA 15220 


\section{DISCLAIMER}

"This report was prepared as an account of work sponsored by an Agency of the United States Government. Neither the United States Government nor any agency thereof, nor any of their employees, makes any warranty, express or implied, or assumes any legal liability or responsibility for the accuracy, completeness, or usefulness of any information, apparatus, product, or process disclosed, or represents that it use would not infringe privately owned rights. Reference herein to any specific commercial product, process, or service by trade name, trademark, manufacturer, or otherwise, does not necessarily constitute or imply endorsement, recommendation, or favoring by the United States Government or any agency thereof. The views and opinions of authors expressed herein do not necessarily state or reflect those of the United States Government or any agency thereof."

"This report has been reproduced from the best available copy. Available in paper copy and microfiche"

Number of pages in report: 73

DOE and DOE contractors can obtain copies of this report

FROM: Office of Scientific and Technical Information, P.O.

Box 62, Oak Ridge, TN 37831. (615) 576-8401

This report is publicly available from the department of Commerce, National Technical Information Service, 5285 Port Royal Road, Springfield, VA 22161. (703) 487-4650. 
Table of Contents

Table of Contents

List of Figures

List of Tables

Executive Summary

1.0 Summary

2.0 Introduction

2.1 The Blast Furnace Process

3.0 Used Oil Filters

3.1 Generation Rate

3.2 Geographic Distribution of Used Oil Filters

3.3 Filter Composition

3.3.1 Gross Filter Weights __ 6

3.3.2 Steel Coatings $\quad-7$

3.3.3 Fuels

3.3.4 Used Oil Filter Components $\quad 8$

3.3.5 Oil Filter Dry Material Weight Percentages $\quad 9$

3.4 Energy Values for Contained Oil and Filter Media $\quad 10$

3.5 Current Methods of Processing of Used Oil Filters $\quad 10$

3.6 Present Disposal of Used Oil Filters 11

3.6.1 Recycling at Steel Plants and Foundries -11

3.6.2 Individual State Laws Governing Oil Filter Recycling $\quad 12$

4.0 Blast Furnace $\quad 13$

4.1 Blast Furnace Geographical Distribution $\quad 13$

\begin{tabular}{ll}
4.2 Current Operating Practice & 13 \\
\hline $4.2 .1 F$
\end{tabular}

\begin{tabular}{ll}
4.2 .1 Fuel & 14 \\
\hline 4.2 .2 ron & 14 re
\end{tabular}

4.2 .2 Iron Ore $-\frac{14}{14}$

4.2 .3 Metallics $-\frac{14}{14}$

\begin{tabular}{ll}
4.2 .4 Fluxes & 15 \\
\hline 4.2 .5 Production & 15
\end{tabular}

4.2.5 Production

4.2.6 Hot Metal Chemistry -15

4.2.7 Slag Chemistry __._.

4.2.8 Gas Cleaning 16

4.2.9 Waste Water Cleaning $\frac{16}{16}$

4.3 Recycling of Used Oil Filters to the Blast Furnace -16

4.3.1 Material Handling and Storage -20

4.3.2 Size Requirements $-\frac{20}{20}$

4.3.3 Effect on Blast Furnace Process $\quad-21$

4.3.3.1 The Chemistry of Motor Oil in the Blast Furnace $\quad 21$ 
4.3.3.1.1 Composition and Properties of Motor Oil 23

$\begin{array}{ll}\text { 4.3.3.1.2 Distillation of Oil in the Blast Furnace } & 27\end{array}$

\begin{tabular}{ll}
4.3 .3 .1 .3 Reactions of Oil in the Blast Furnace & 27 \\
\hline
\end{tabular}

4.3.3.2 Fuel Value Recovered $\quad 30$

4.3.3.3 Top Gas Chemistry $\quad 31$

\begin{tabular}{ll}
\hline 4.3.3.4 Metallics Recovered & 31 \\
\hline 4.3 .3 .5 & 31 S
\end{tabular}

4.3.3.5 Slag Chemistry $\quad 32$

4.3.3.6 Hot Metal Chemistry $\quad 32$

4.3.3.7 Burden Permeability $\quad 32$

4.3.4 Process Flow Diagram $\quad 32$

4.3.5 Effect on Gas Cleaning

4.3.6 Effect on Blast Furnace Gas Heating Value $\quad-35$

5.0 Capital Cost Considerations 36

5.1 Storage $3 \frac{36}{36}$

5.2 Handling and Charging 3.36

5.3 Processing of Oil Filters -36

5.4 Top Gas Cleaning $\quad 37$

5.5 Waste Water Cleaning $\quad-37$

6.0 Operating Cost Considerations

6.1 Hot Metal Production $\quad \frac{38}{39}$

6.2 Slag Production $\quad 39$

6.3 Top Gas Production $\quad 39$

6.4 Fuel Requirements $\quad 3 \frac{39}{39}$

6.5 Flux Requirements $\quad 39$

6.6 Iron Yield 39

6.7 Gas Cleaning $\quad 39$

6.8 Waste Water Treatment $\quad 40$

7.0 Analysis

7.1 Operational Considerations $\quad-\frac{41}{42}$

7.2 Cost/Benefit Review

8.0 Review with Blast Furnace Operators 44

8.1 Past Experiences with Oily Charge Materials $\quad 44$

8.2 Perceived Problems with Charging Oil Filters $-\frac{44}{46}$

9.0 Future Work $\frac{46}{47}$

10.0 Conclusions

11.0 Acknowledgements $\quad \frac{48}{49}$

12.0 Appendix $\quad 49$

13.0 References $\quad-56$

14.0 Resumes 


\begin{tabular}{|llr|}
\hline List of Figures & & 3 \\
\hline & & \\
\hline Figure 1: & The Blast Furnace Process & 22 \\
\hline Figure 2: & Schematic representations of blast furnace time and & 29 \\
\hline & Temperature relationships, approximate & \\
\hline Figure 3: & Flow diagram outlining the pyrolysis of Gas Oil shown in & 30 \\
\hline & Table 15 & 33 \\
\hline Figure 4: & Flow diagram for the production of coke. Any hydrocarbon & 34 \\
\hline & Can yield catalytic carbon in the presence of some \\
\hline Figure 5: & Materials. f.r.r. = Free-radical reactions. & \\
\hline Figure 6: & Blast furnace material balance for a conventional practice & \\
\hline & Blast furnace material balance for a 2\% recycle rate of used & \\
\hline Figure 7: & Oil filters in the burden & Some typical aromatics from hydrocarbon pyrolysis. 57 \\
\hline & 57 Molecules with 2 or more rings are known as polycyclic & \\
\hline
\end{tabular}




\begin{tabular}{|c|c|c|}
\hline List of Tables & . & \\
\hline \multicolumn{3}{|l|}{8} \\
\hline Table 1: & Used Oil Filters Available for Recycling 2001 to 2005 & 5 \\
\hline Table 2 : & New Oil Filter Weights & 6 \\
\hline Table 3: & Estimate of Oil Contents in an Average Used Oil Filter & 8 \\
\hline Table 4: & Oil Filter Dry Component Weight Content & 10 \\
\hline Table 5: & USA Blast Furnace Locations & 13 \\
\hline Table 6 : & Hot Metal Chemistry & 15 \\
\hline Table 7: & Slag Chemistry & 16 \\
\hline \multirow[t]{3}{*}{ Table 8: } & Charging Weights and Percentages of Used Average Oil & \\
\hline & Filter Components at a $50 \%$ Recycling Rate Based on & \\
\hline & Current Oil Filter Generation Data & 18 \\
\hline \multirow[t]{3}{*}{ Table 9: } & Charging Weights and Percentages of Used Average Oil & \\
\hline & Filter Components at a $70 \%$ Recycling Rate Based on & \\
\hline & Future Growth & 19 \\
\hline Table10: & Ingredients of Fresh Motor oil & 23 \\
\hline Table11: & Hydrocarbon Group Analysis of Used Motor oil & 24 \\
\hline Table12: & Concentrations of PAHs Found in One Sample of Motor Oil & 25 \\
\hline Table13: & Metal Contents of Used Oil & 26 \\
\hline Table14: & Non-metal Inorganic Content of Used Oil & 26 \\
\hline Table15: & Compositions of Used Oil and Other Fuels & 26 \\
\hline \multirow[t]{2}{*}{ Table16: } & Antoine Parameters for Various Hydrocarbons (Appendix 4, & \\
\hline & Eq. 2) & 27 \\
\hline \multirow[t]{2}{*}{ Table17: } & Results of the Pyrolysis of Partially Hydrogenated Gas Oil & \\
\hline & With a Temperature Profile between $1292-1526^{\circ} \mathrm{F}$ & 28 \\
\hline \multirow[t]{3}{*}{ Table18: } & Calculated results of the composition of the products of & \\
\hline & Pyrolysis of used motor oil to obtain average molecular & \\
\hline & Weight & 31 \\
\hline \multirow[t]{2}{*}{ Table19: } & Relative Cost vs. Benefit of Charging Used Oil Filter to the & \\
\hline & Blast Furnace & 43 \\
\hline
\end{tabular}




\section{Executive Summary}

This feasibility study has indicated that of the approximately 120,000 tons of steel available to be recycled from used oil filters (UOF's), a maximum blast furnace charge of $2 \%$ of the burden may be anticipated for short term use of a few months. The oil contained in the most readily processed UOF's being properly hot drained and crushed is approximately $12 \%$ to $14 \%$ by weight. This oil will be pyrolized at a rate of $98 \%$ resulting in additional fuel gas of $68 \%$ and a condensable hydrocarbon fraction of $30 \%$, with the remaining $2 \%$ resulting as carbon being added into the burden.

Based upon the writer's collected information and assessment of the calculations on the pyrolysis of the motor oil, there does not appear to be any operational problems relating to the recycling of UOF's to the blast furnace. Any free draining of oil in the transportation, handling, and storage of UOF's prior to their charging must be contained. Although, the EPA does not consider UOF's hazardous, five states have enacted legislation banning the placement of UOF's into state landfills.

Upon reviewing the preliminary study work with blast furnace operators, it was learned that US Steel at Gary Works has been routinely charging UOF's at about 100 tons to 200 tons per month for many years. Discussions with the USS operating and scrap purchasing personnel have indicated no adverse effect to their blast furnace operation nor in the handling and storage of the UOF's with their specification of "no free flowing oil". The remaining oil content in these UOF's is not presently known.

The following sections will provide detailed information regarding the generation rate of used oil filters, their geographical disposition, and their potential quantities available for recycling. Although the contained oil quantities are a relatively small percentage of the blast furnace burden, extensive analysis and calculations have been done to indicate the most probable result of the pyrolysis of the oil within the blast furnace. There does not appear to be any toxic consideration as a result of this pyrolysis within the blast furnace. However, a hydrocarbon condensate in the "gasoline" fraction will condense in the blast furnace scrubber water and may require additional processing in the water treatment system to remove benzene and toluene from the condensate.

Used oil filters represent an additional source of high quality iron units that may be effectively added to the charge of a blast furnace for beneficial value to the operator and to the removal of this resource from landfills. 


\section{A Feasibility Study for Recycling Used Automotive Oil Filters in a Blast Furnace}

\subsection{Summary}

This feasibility study has indicated that of the approximately 120,000 tons of low residual steel available to be recycled from used oil filters (UOF's), a maximum blast furnace charge of $2 \%$ (40 lb/NTHM) of the burden may be anticipated for short term use of a few months due to limited availability of the UOF's. The oil contained in the most readily processed UOF's being properly hot drained and crushed is approximately $12 \%$ to $14 \%$ by weight. This oil (and filter media) charged (about $10 \mathrm{lb} / \mathrm{NTHM}$ ) will be pyrolized into lighter hydrocarbons of $98 \%$ of the oil and media charge weight, resulting in additional fuel gas of $68 \%$ ( $7 \mathrm{lb} / \mathrm{NTHM})$ and a condensable hydrocarbon fraction of $30 \%(7 \mathrm{lb} / \mathrm{NTHM})$, with the remaining $2 \%(1 \mathrm{lb} / \mathrm{NTHM})$ resulting as carbon being added into the burden.

Based upon the writer's collected information and assessment of the calculations on the pyrolysis of the motor oil, there does not appear to be any operational problems relating to the recycling of UOF's to the blast furnace. Any free draining of oil in the transportation, handling, and storage of UOF's prior to their charging must be contained. Although, the EPA does not consider UOF's hazardous, five states have enacted legislation banning the placement of UOF's into state landfills.

Upon reviewing the preliminary study work with steel plant personnel, it was learned that one USA blast furnace operator has been routinely charging UOF's at about 100 tons to 200 tons per month for many years. The current cost of these UOF's is about $\$ 30$ per gross ton delivered to the company's plant. Discussions with the company's operating and scrap purchasing personnel have indicated no adverse effect to their blast furnace operation or in the handling and storage of the UOF's with their specification of "no free flowing oil". The remaining oil content in these UOF's is not presently known.

The following sections will provide detailed information regarding the generation rate of used oil filters, their geographical disposition, and their potential quantities available for recycling. Although the contained oil quantities are a relatively small percentage of the blast furnace burden, extensive analysis and calculations have been done to indicate the most probable result of the pyrolysis of the oil within the blast furnace. There does not appear to be any toxic consideration as a result of this pyrolysis within the blast furnace. However, a hydrocarbon condensate in the "gasoline" fraction will condense in the blast furnace scrubber water and may require additional processing in the water treatment system to remove the light oils from the condensate.

Used oil filters represent an additional source of high quality iron units that may be effectively added to the charge of a blast furnace for beneficial value to the operator and to the removal of this resource from landfills. 


\subsection{Introduction}

This study is the result of a solicitation by the American Iron \& Steel Institute for "A Feasibility Study for Recycling Used Automotive Oil Filters in a Blast Furnace" as dispatched by e-mail 11 May 2001. In the AISI, "Steel Technology Road Map", March, 1998, section 3.2.3 AUTOMOTIVE, there is a commentary on recycling of automotive scrap. Oil filters represented the greatest potential source of currently un-recycled automotive steel scrap. The Steel Technology Roadmap indicated potential iron units of 65,000 tons from oil filters to be available. This is contrasted with more than $12,000,000$ tons of shredded steel scrap from automobiles in 1994 . $^{1}$

There has been considerable work done over the past ten years concerning the potential for recycling of used automotive oil filters. Professor K. D. Peaslee of the University of Missouri-Rolla, Department of Metallurgical Engineering, has done a significant amount work over many years regarding the potential for recycling of used automotive oil filters. Much of this work is summarized in a current technical bulletin. ${ }^{2}$

A study by "The Convenient Automotive Services Institute"3 showed that, based on their testing of used oil filters, the oil filters appeared to be non-hazardous with respect to EPA classifications.

This AISI feasibility study has relied mainly on published work and information gathering via the Internet to obtain the background information regarding the generation rate and location of used oil filters (UOF's) in the United States. This information is presented in detail in the following sections of the study. A $100 \%$ recycling rate of current UOF's has the potential for 120,000 tons of steel to be available for recycling. This is to be placed in perspective to the approximately $50,000,000$ tons/year of blast furnace iron production in the United States. Therefore, in the writer's opinion, the most likely maximum charging rate of UOF's to the blast furnace would be less than $2 \%$ of the burden.

Section 3.3 Composition, then focuses on the oil content of the UOF's along with any potential metals contamination. The results show the metal to be a high quality, low residual source of iron units. Particular emphasis is placed on the pyrolysis of oil as the UOF's enter the blast furnace and become heated within the burden. This study will show that $98 \%$ of the oil entering the blast furnace in the UOF will leave with the top gas as both fuel gas and a condensable hydrocarbon fraction.

Communications with blast furnace operating personnel were conducted to determine any actual operating experience with UOF's, or their perceived potential problems concerning the charging of used oil filters to the blast furnace. The

\footnotetext{
${ }^{1}$ AISI, “Steel Technology Roadmap”, March 1998, section 2.2.3 AUTOMOTIVE, pg 77.

${ }^{2}$ Technical Bulletin, "The Future of Used Oil Filter Recycling in Missouri: An Evaluation of Potential Processes, Product Quality, Recycling Locations, and Economics”, February 15, 1997, K.D. Peaslee and D.E. Roberts, II, University of Missouri-Rolla, Department of Metallurgical Engineering.

3 "Report of the Findings on the Waste Classification of Used Automotive Oil Filters", The Convenient Automotive Services Institute, April 1991.
} 
discussions with the US Steel operators identified that they have been charging UOF's at the Gary Works for many years as indicated in section 8.0.

A qualitative cost benefit analysis is presented by the writers to assist the assessment of the potential value for recycling UOF's to the blast furnace in section 7.0. The section 9.0 "Future Work" is directed toward enhancing the recovery of UOF's for beneficial recycling to the blast furnace.

\subsection{The Blast Furnace Process}

As an aid to assist persons who may not be familiar with the iron blast furnace, a pictorial representation of the blast furnace process has been downloaded from the AISI web site ${ }^{4}$ as shown below in Figure 1.

\section{the process}

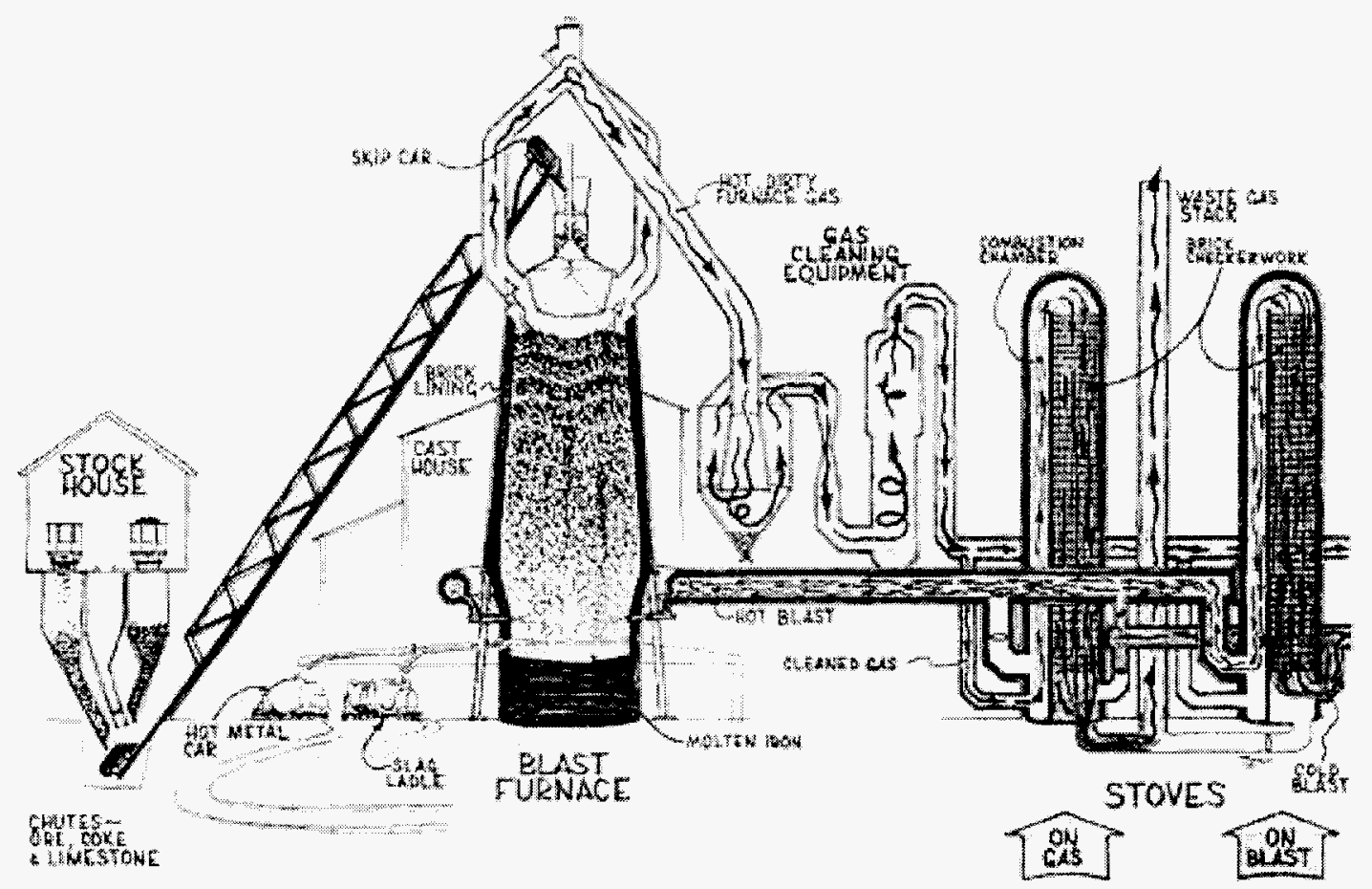

Figure 1: The blast furnace process ${ }^{4}$

\footnotetext{
4 "The Process," From "An Introduction to Blast Furnace Technology", ATSI Engineering Services, http://www.steel.org/learning/howmade/blast furnace.htm, 12/17/2001.
} 


\subsection{Used Oil Filters}

\subsection{Generation Rate}

Used oil filters are generated from a number of sources. Light duty pickup trucks, derivatives thereof and automobiles generate the most oil filters. Other applications producing used oil filters would be medium and heavy duty trucks, stationary internal combustion engines, off road vehicles, motorcycles, construction machinery, hydraulic power generation units, railroad locomotives, aircraft and auxiliary power units.

A used oil filter is produced every time an oil filter in use is replaced with a new filter. Very few oil lubrication filters are cleaned and reused. The current state of the art filters are designed to trap particles as small as 8 to 10 microns in a fibrous media that precludes flushing and regeneration. ${ }^{5}$

A quick examination of automobile maintenance instructions shows that under normal driving conditions, oil changes are recommended every 7500 miles and an oil filter change is recommended every other oil change. However under "severe" circumstances such as driving in a dusty area, towing a trailer, frequent idling or driving 4 miles or less in freezing weather the recommended change interval for both the oil and oil filter is 3000 miles. Most commercial oil change facilities recommend an oil and filter change every 3000 miles, even to the point of putting a reminder sticker on the windshield.

Certain cars today have oil change indicators lights built into the instrument cluster. An algorithm based on the number of engine starts, total engine revolutions, miles driven, and etc., since the last oil change flashes a signal when an oil change is needed. However, in order to keep the warranty in force, a driver needs to follow the written recommendations included with the owner's manual.

Lubricant analysis for predictive analysis of oil changes and engine conditions has become a useful tool for railroads, automotive and trucks fleets and aircraft businesses. On a regular basis, a sample of oil is taken from an internal combustion engine and checked for viscosity, physical appearance, metal content, water, and coolant contamination. ${ }^{6}$ A major consumer of lubricating oil may set up a complete laboratory while private analysis service for individual automobile owners are available through the oil companies. ${ }^{7}$ While widespread adoption of this method would lead to better prediction of a used oil filter generation rate, however cost and inconvenience would preclude the normal owner of a motor vehicle from this service.

\footnotetext{
5 "AC Delco - Parts Information-Oil Filters-Ultraguard Gold," http://www.acdelco.com/pi filt oil gold feature.htm, 9/24/01

${ }^{6}$ F.E. Lockwood and R. Dailey, "Lubricant Analysis," Friction, Lubrication and Wear Analysis, 1992, ASM Handbook, Vol. 18, pp. 299-312

7 "Online Sample Report, Oil Sampling Guidelines," http://www.thetakgroup.com/pennzoilquakerstate/pqs/login.asp, 10/25/01
} 
On the one hand, the commercial oil change facilities are advocating more frequent oil changes while on the other hand, there will be a large percentage of drivers who greatly extend the mileage or time between oil filter changes.

In the USA and Puerto Rico in 1999 there were 222,564,582 registered motor vehicles. ${ }^{8}$ This total includes all automobiles, trucks and motorcycles in private and public service. The Oil Filter Recycling Council estimates that approximately $440,000,000$ used oil filters will be generated in the USA in year 2001 while historical trends indicate about a $1 \%$ increase per year; ${ }^{9}$ this is roughly two oil filter changes for every registered motor vehicle in the USA. The generation of $440,000,000$ oil filters per year seems reasonable given the number of registered motor vehicles and the fact that it is impossible for one person to operate more than one vehicle at a time.

From 1998 to 1999 the oil filter-recycling rate increased from 33 to $50 \%$ as indicated in a survey of filter recyclers. ${ }^{10}$ For year 2001 the Oil Filter Recycling Council estimated a recycling rate of between 40 to $50 \%$. ${ }^{11}$ The recycling rate is dependent on state laws and growth of oil change facilities sending filters to recyclers. The recycling rate is expected to exhibit continued growth.

To predict the number of used oil filters generated for recycling in a blast furnace up to the year 2005, one needs the total annual oil filter units of production and the increase in recycling rates. A production rate increase of $1 \%$ per year is known. For the purposes of this study, a $5 \%$ per year increase in recycling is assumed.

Table 1: Used Oil Filters Available for Recycling 2001 to 2005

\begin{tabular}{|l|l|l|l|}
\hline Year & $\begin{array}{l}\text { Total New Oil Filter } \\
\text { Units }\end{array}$ & $\begin{array}{l}\text { Oil Filter Recycling } \\
\text { Rate }\end{array}$ & $\begin{array}{l}\text { Oil Filter Units } \\
\text { Available for } \\
\text { Recycling }\end{array}$ \\
\hline 2001 & $440,000,000$ & $50 \%$ & $220,000,000$ \\
\hline 2002 & $444,400,000$ & $55 \%$ & $244,400,000$ \\
\hline 2003 & $448,800,000$ & $60 \%$ & $269,300,000$ \\
\hline 2004 & $453,300,000$ & $65 \%$ & $294,700,000$ \\
\hline 2005 & $457,900,000$ & $70 \%$ & $320,500,000$ \\
\hline
\end{tabular}

According to this prediction an increase of $46 \%$ by 2005 is expected in the number of oil filter units generated for recycling.

In all 50 states and Puerto Rico disposal of motor oil on or in the ground is illegal. Used oil filters are classified by the EPA as a non-hazardous material if they are not terne plate (coated with a mixture of tin and lead). As a result all commercially available

\footnotetext{
8 "State Motor Vehicle Registration 1999 Table MV-1,"

http://wwwcf.fhwa.dot.gov/ohim/hs99/tables/mv1.pdf, 10/25/2001

${ }^{9}$ Brent Hazelett, "Private Communications," Oil Filter Manufacturers Council, September 25, 2001.

10 "Recycle Rate for Used Oil Filters." http://www.filtercouncil.org/news/May2000.html, (Filter

Manufacturers Council, FMC PR 01-00, May 4, 2000).

${ }^{11}$ Brent Hazelett, "Private Communications," Oil Filter Manufacturers Council, September 25, 2001.
} 
oil filters are now provided with a galvanized or tinplate coating. Depending on state laws, a "do it yourselfer" or oil change facility can dispose of properly drained used oil filters in a landfill. Future improvements in oil filter recycling rates may be dependent on eliminating landfills as a place of oil filter disposal and economic incentives for recycling oil filters.

\subsection{Geographic Distribution of Used Oil Filters}

Wherever there are internal combustion engines, there are used oil filters. The U.S. Department of Transportation compiles statistics on motor vehicle registrations by state including Puerto Rico. By using the assumption of two oil filter changes per year as was previously discussed and a $50 \%$ recycling rate, one can estimate the number of recyclable oil filters generated yearly in each state as shown in Appendix 1.

Crushing and separation of non-metallic elements reduces the average weight of a used oil filter from $10 \mathrm{oz}$ to $8.81 \mathrm{oz}$. Based on 2 oil filter changes per year, $222,564,582$ registered motor vehicles with an average steel weight in an oil filter of 8.81 oz there would be a maximum of 122,550 tons of steel available for blast furnace melting.

\subsection{Filter Composition}

\subsubsection{Gross Filter Weights}

New oil filter weights vary considerably depending on the size of the filter. Listed below are some designations and gross weights for oil filters, Table 2 . The gross weight includes all components including steel, filter media material and rubber.

Table 2: New Oil Filter Weights

\begin{tabular}{|l|l|l|}
\hline Information Source & Oil Filter Designation & Gross Weight (oz, g) \\
\hline $\begin{array}{l}\text { Oil Filter Manufacture } \\
\text { Council }\end{array}$ & Average Filter (estimate) & $10 \mathrm{oz}, 283 \mathrm{~g}$ \\
\hline ArvinMeritor & & \\
\hline ArvinMeritor & & \\
\hline Delphi $^{15}$ & Small Filter & $7.87 \mathrm{oz}, 223 \mathrm{~g}$ \\
\hline Delphi $^{16}$ & Medium Filter & $12.59 \mathrm{oz}, 357 \mathrm{~g}$ \\
\hline & Small Filter & $8.29 \mathrm{oz}, 235 \mathrm{~g}$ \\
\hline & Large Filter & $15.70 \mathrm{oz}, 445 \mathrm{~g}$ \\
\hline
\end{tabular}

Since there are over 100 different types of commercially available oil filters, a weighted average weight would involve determining both the amount sold in each category and individual weights. For purposes of this feasibility study a simple average

\footnotetext{
12 Brent Hazelett, "Private Communications," Oil Filter Manufacturers Council, September 25, 2001.

${ }^{13}$ Nishaj Attassery, "Private Communications," 16 Oct 2001, Email Letter, ArvinMeritor

${ }^{14}$ Ibid

${ }^{15}$ Mike Whitman, "Private Communications," 12 Oct 2001, Fax Memo, Delphi Corporation

${ }^{16}$ Ibid
} 
of the above gross weights will be used as the basis for calculation. The gross average weight includes all oil filter components for new filters.

\subsubsection{Steel Coatings}

Coated steels are used in oil filters. Tin plate or galvanized steels are used for the can, top and bottom plates and center tube. ${ }^{17}{ }^{18} \mathrm{Wix}$, Delphi, Fram and ArvinMeritor reported using tin plate and uncoated steels in their filters. ${ }^{19}{ }^{20} 21{ }^{22} \mathrm{~A}$ coating of $0.25 \mathrm{lb}$. tin per base box is usually specified for oil filter applications. ${ }^{23} \mathrm{~A}$ base box is 31360 square inches. The tin coating is always applied to both sides of a sheet for an oil filter application. This would mean that approximately $0.125 \mathrm{lb}$ tin is present every 31360 square inches of surface area. This works out to a 15 micro inch thick tin coating on each side.

If galvanized steel is specified for an oil filter the coating weight is usually $0.10 \mathrm{oz}$ per square foot of surface area for one side. ${ }^{24}$ This means the zinc coating thickness is 275 micro inches per side. Zinc is electrolytically applied to both sides for oil filter applications.

The cans for oil filters are made using a drawn and iron process. Steel thickness will be reduced around $20 \%$ during the drawing operation. Likewise the coating thickness is reduced $20 \%$ at the same time. The amount of thickness reduction and associated steel elongation is highly dependent on the design of the irons and dies used in the process. Stamped parts such as the top and bottom plates will not experience thickness reduction.

An earlier study melted crushed oil filters in an induction furnace. ${ }^{25}$ Reported residual tin levels ranged from 0.026 to $0.035 \mathrm{wt}$. \%. No values were reported for zinc due to the fact that zinc will volatilize during air or vacuum melting operations. Zinc causes problems due to re-condensation causing accumulation within the blast furnace operation. $^{26}$

If an oil filter manufacturer uses galvanized steel for the can it is possible to roughly estimate the weight of the zinc coating. Based on known zinc coating weights per square foot, the weight of zinc may be determined, as shown in Appendix 2. The information used to estimate the surface area of the can was obtained from a study of oil filter construction and quality. ${ }^{27}$ The estimate is based on the calculated surface area for

\footnotetext{
17 "Tin Plate," http://www.weirton.com/products/tin/tinplate.html, 24 Sep 2001

18 "Weirzin," http://www.weirton.com/products/galv/weirzin.html, 24 Sep 2001

${ }^{19}$ Brent Hazellet, "Private Communications," Oil Filter Manufacturers Council, 18 Oct 2001

${ }^{20}$ Mike Whitman, "Private Communications," 13 Oct 2001, Phone Message, Delphi Corporation

${ }^{21}$ Scott Jacobs, "Private Communications," 24 Oct 2001, Email Letter, Fram Brand, Honeywell Corp.

${ }^{22}$ Nishaj Attassery, "Private Communications," 16 Oct 2001, Email Letter, ArvinMeritor

${ }^{23}$ Edward Adamczyk, "Private Communications," Weirton Steel, Phone Message, 11 Oct 2001.

${ }^{24}$ Ibid

${ }^{25}$ Kent D. Peaslee, "Recycling Used Automotive Filters," Journal of Metals, February, 1994, pg. 46

${ }^{26}$ Harold E. McGannon, ed., The Making Shaping and Treating of Steel, (Pittsburgh: United States Steel, 1971),pg. 456

27 "Engine Oil Filter Study," http://www.scuderiaciriani.com/rx7/oil filter study/, 11 Oct 2001.
} 
both the inside and outside of the can, and the thickness reduction due to drawing and original zinc coating weight.

Data was given for the cartridge cylinder dimensions in the study. The cartridge is the filtration media element inside the can. Surrounding the filter media cartridge is the can. By increasing the filter cartridge diameter and height by 10 and $20 \%$ respectively, the surface area of the can cylinder can be readily calculated.

Based on this calculation, an average filter using a zinc coating on the can will contain $0.00369 \mathrm{lbs} \mathrm{Zn}(0.059 \mathrm{oz}, 1.67 \mathrm{~g})$. This would result in a minimum zinc content of $0.54 \%$ in the average filter.

\subsubsection{Fuels}

When a filter is removed from an engine it contains oil. While there are various methods for draining the filter prior to and after removal, some residual oil will always remain as shown in Table 3. As measured by ArvinMeritor and Delphi, oil filters can hold anywhere from $8 \mathrm{oz}$. $(227 \mathrm{ml})$ to $22 \mathrm{oz}(624 \mathrm{ml}) .{ }^{28}{ }^{29}$ An average oil filter will contain around $16 \mathrm{oz}$ (liquid) of oil. ${ }^{30}$ Just after removal, an improperly drained filter will contain $70 \%$ of its original oil volume. Even after properly hot-draining a filter, studies have shown that approximately $40 \%$ of the weight of a used filter remains due to used oil $(6$ to 8 ounces). ${ }^{31}$ Proper draining and crushing of used oil filters will remove up to $88 \%$ of the oil in a used filter. ${ }^{32}$

Table 3: Estimates of Oil Contained in an Average Used Oil Filter

\begin{tabular}{|l|l|l|}
\hline Filter Condition & Oil Volume & Oil Weight \\
\hline Full & $16 \mathrm{oz} .(454 \mathrm{ml})$ & $14.69 \mathrm{oz}$. \\
\hline Improperly Drained & $11.2 \quad(331 \mathrm{ml})$ & 10.27 \\
\hline Properly Hot Drained & $6.4 \quad(189 \mathrm{ml})$ & 5.87 \\
\hline Drained and Crushed & $1.9 \quad(56 \mathrm{ml})$ & 1.74 \\
\hline
\end{tabular}

\subsubsection{Used Oil Filter Components}

The main parts of a disposable spin-on oil filter are the can, base plate, center tube, top and bottom plates, springs, filter media cartridge and rubber gasket. In some filters a dusting of Teflon is blown onto the rubber gasket. Corrosion proof $\mathrm{TiO}_{2}$ based paint is used to coat the outside of the filter for protection from the elements and brand identification.

\footnotetext{
${ }^{28}$ Nishaj Attassery, "Private Communications," 16 Oct 2001, Email Letter, ArvinMeritor

29 Mike Whitman, "Private Communications," 17 Oct 2001, Phone Message, Delphi Corporation

${ }^{30}$ Brent Hazelett, "Private Communications," Oil Filter Manufacturers Council, September 25, 2001.

31 Ibid.

${ }^{32}$ Kent D. Peaslee, "Recycling Used Automotive Filters," Journal of Metals, February 1994, pg. 44.

${ }^{33}$ Note: Lubricating Oil Specific Gravity can vary from 0.856 to 0.913 . For purposes of this study a value of 0.88 will be used. "Material Data Safety Sheet," Havoline Motor Oil, http://www.equivatexacomsds.com/rd/getsinglemsds.asp?ID=191113, 18 Sep 2001.
} 
(1) The Filter Body or Can is a container for filter parts, which is made of steel specifically designed to withstand the normal automotive operating environment as well as start-up pressure surges. Weirton Steel lists the use of tinplate and galvanized sheet steel for this application. ${ }^{34}$

(2) The Base Plate is a thick metal plate which supports the filter and provides secure engine mounting for easy spin on installation. This is normally made from an uncoated hot or cold rolled low carbon steel.

(3) The Center Tube provides support to the filtering media. The center tube is usually made out of tin plate or galvanized steel and perforated with holes to allow the passage of oil.

(4) The Top and Bottom Plates are a metal disks positioned on the top and bottom of the filter media. The plates are used to slightly compress and keep the filtration media in proper position. They are usually made from tin plate or galvanized steel.

(5) Springs are used in the anti backflow valve. The combination valve assembly includes a pressure relief (bypass) valve to assure oil flow to the engine if the filter should plug from extended use beyond the recommended service life or when the weather is cold and the oil is thick and flows slowly. They are normally made from plain carbon steel.

(6) The Filter Media Cartridge is the component of the system, in which the oil is actually filtered to remove the particulate contamination. Almost all filter media is made out of paper with a very small percentage made from synthetic fibers.

(7) The Gasket is the resilient rubber material (nitrile rubber) that provides a positive seal between the filter and engine mount.

\subsubsection{Oil Filter Dry Material Weight Percentages}

A previous study determined the component weight on a percentage basis for light duty and heavy-duty oil filters, Table $4 .^{35}$

\footnotetext{
${ }^{34}$ Weirton Steel Internet Site

${ }^{35}$ Kent D. Peaslee and Darrell E. Roberts, "Characterization of used automotive oil filters for recycling," Resources, Conservation and Recycling 19(1997), pg 86.
} 
Table 4: Oil Filter Dry Component Weight Content

\begin{tabular}{|l|l|l|l|l|}
\hline $\begin{array}{l}\text { Oil Filter } \\
\text { Component }\end{array}$ & $\begin{array}{l}\text { Light Duty } \\
\text { Filter }\end{array}$ & $\begin{array}{l}\text { Heavy Duty } \\
\text { Filter }\end{array}$ & $\begin{array}{l}\text { Average } \\
\text { Percentage for } \\
\text { all Filters }\end{array}$ & $\begin{array}{l}\text { Weight of } \\
\text { Component } \\
\text { For an Average } \\
\text { Oil Filter - } \\
10.89 \mathrm{oz}\end{array}$ \\
\hline Can & $31 \%$ & $32 \%$ & $32 \%$ & $3.48 \mathrm{oz}$ \\
\hline Base Plate & 32 & 22 & 27 & 2.94 \\
\hline Center Tube & 7 & 10 & 9 & 0.98 \\
\hline $\begin{array}{l}\text { Top/Bottom } \\
\text { Plates }\end{array}$ & 9 & 7 & 8 & 0.87 \\
\hline Springs & 5 & 4 & 5 & 0.54 \\
\hline Filter Media & 12 & 20 & 16 & 1.74 \\
\hline Rubber & 3 & 2 & 3 & 0.34 \\
\hline
\end{tabular}

By adding up the weights for the steel components one finds that the weight of steel in an average oil filter is $8.81 \mathrm{oz}(249.8 \mathrm{~g})$.

\subsection{Energy Values for Contained Oil and Filter Media}

An energy value used by a major electrical provider is 133,000 Btu per gallon for used motor oil. ${ }^{36}$ At a specific gravity of 0.88 this is approximately $18,000 \mathrm{Btu} / \mathrm{lb}$ of used motor oil. Energy values for dry paper (filter media) typically average around $10,000 \mathrm{Btu} / \mathrm{b} .^{37}$ Due to the small weights involved, energy values for the paint on the oil filter and nitrile rubber gasket are minimal and will not be considered in this study.

\subsection{Current Methods of Processing of Used Oil Filters}

Used oil filters obtained by recyclers are generally crushed into pucks, shredded, or made into scrap bales. In many scrap-processing operations, a shredder, which

includes a hammermill, both shreds and pounds the pieces into mill nuggets. ${ }^{38}$ Oil flows out of the shredder into a collector box. A magnetic drum is used to separate the ferromagnetic metallic parts from the paper element and rubber gasket. The metal parts can then be screened into 1 in, 2 in, 3 in, 4 in or larger fragments. ${ }^{39}{ }^{40}$ The paper is then sold

\footnotetext{
${ }^{36}$ Santee Cooper Electric Utility, "GOFER, Give Oil For Energy Recovery," http://www.scgofer.org/about.html, November 12, 2001

${ }^{37}$ Wisconsin Energy Bureau. "Paper Pellets for Industrial Fuel," www.wifocusonenergy.com, November 11,2001 .

38 Bill Vajdek, "Private Communications," American Resource Recovery, Ltd., Maywood, IL, November 15,2001

${ }^{39}$ Tammi Jones, "Private Communications," Commercial Filter Recycling, Los Angeles, California, October 27, 2001.

${ }^{40}$ Gregory C. Potter, "Private Communications," Oil Filter Recyclers, Inc. Easton, IL, November 13, 2001.
} 
to a waste heat generator. Apparent metallic bulk density after shredding is reported to be about $37 \mathrm{lb} / \mathrm{ft}^{3}$.

Scrap baling is another method of processing used oil filters. Several scrap processors use this method to supply used oil filter metallics to EAF shops. Apparent bulk density for scrap bales was reported around 60 to $80 \mathrm{lb} / \mathrm{ft}^{3}$. Scrap bundles may be as small as $1 \mathrm{ft}^{3}$ up to $2 \mathrm{ft}^{3}$. This material would be too large for charging to a blast furnace.

Another method is crushing the filters in a hydraulic press to form a "puck". One operator then "cooks" the pucks to drive off the remaining oil. ${ }^{41}$ All dimensions of a filter are reduced by about $50 \%$ so the maximum dimension may range from 2 in up to 8 in. Bulk density is around 40 to $45 \mathrm{lb} / \mathrm{ft}^{3}$ for this material. Another scrap dealer compresses the filters into $45 \mathrm{lb}, 10$ in diameter cylinders with hemispherical tops. ${ }^{42}$

As an estimate, uncrushed filters may have an average cylinder size height of 4.5 in and a diameter of 3.5 inches at a weight of $10.89 \mathrm{oz}$. This gives a specific density for an average filter of $27.2 \mathrm{lb} / \mathrm{ft}^{3}$. If the dry filters are put into steel barrel with an assumed $40 \%$ void space, the apparent bulk density would be $16.3 \mathrm{lb} / \mathrm{ft}^{3}$.

For charging to a blast furnace, used oil filters would need to be screened to accommodate operators, unless size control is a part of the process. The scrap yard processors indicated that it would be possible to give blast furnace operators a specified size range of oil filters.

\subsection{Present Disposal of Used Oil Filters}

\subsubsection{Recycling at Steel Plants and Foundries}

An oil filter is considered recycled when the metal portion of the filter is melted by a steel producer or iron foundry and reused for new products. ${ }^{43}$ The US Army has done research into the disposal of used oil filters and the Steel Recycling Institute provided the following list, to the US Army, of primary steel or foundry companies as possible sources for melting used oil filters: ${ }^{44}$

Bayou Steel, Baton Rouge Louisiana

Birmingham Steel, Birmingham, Alabama

Lukens Steel, Allentown, Pennsylvania

Structural Metals, Austin, Texas

US Steel, Pittsburgh, PA

Wheeling-Pittsburgh Steel, Wheeling, WV

Structural Metals, Seguin, Texas

\footnotetext{
${ }^{41}$ Jim Nickerson, "Private Communications," Nickro Recycling Inc., Pittsburg, TX, November 13, 2001.

42 Terry Jones, "Private Communications," Bernell Recycling, Ranch Cucamonga, CA, November 14, 2001.

${ }^{43}$ Brent Hazelett, "Private Communications," Oil Filter Manufacturers Council November 9, 2001.

44 "Disposal of Terne-Plated and Non Terne-Plated Oil Filters," http://chppm-

www.apgea.army.mil/hwmp/Factsheets/OilFilters.html, January, 2001.
} 
TAMCO, Ranch Cucamonga, California

U.S. Foundry \& Manufacturing, Medley, FL

The 2001 recycling rate at $220,000,000$ UOF's, or $50 \%$ is in the range of 87,000 tons to 115,000 tons depending on the residual oil content of Hot Drained and Crushed UOF's and Hot Drained UOF's only. These recycled UOF's are melted in iron foundry cupolas and electric arc furnace steelmaking plants, with a small amount, at about 2,000 tons melted in the blast furnace (see section 8.1).

\subsubsection{Individual State Laws Governing Oil Filter Recycling ${ }^{45}$}

Disposal of drained non terne-plated oil filters in landfills is an acceptable disposal method in most states. However, terne plate oil filters were quickly eliminated from commerce because of the lead contribution. Even so, some states are in the process of revising their regulations to make landfilling of used oil filters illegal. In fact, five states generally prohibit the non-hazardous disposal of used oil filters in landfills: Texas, Rhode Island, Florida, California and Minnesota.

A summary of the relevant rules encompassing used oil filter disposal by state is given in Appendix 3.

45 "Used Filter Management Regulations," Oil Filter Manufacturers Council, http://filtercouncil.org/regs/ 


\subsection{Blast Furnace}

\subsection{Blast Furnace Geographical Distribution}

As of October 21, 2001 there are 19 separate steel plants with at least one operating blast furnace as detailed in Table 5.

Table 5: USA Blast Furnace Locations ${ }^{46}$

\begin{tabular}{|l|l|}
\hline Steel Company & Location of Blast Furnace \\
\hline Acme Steel Co. & Chicago, IL \\
\hline AK Steel Corp & Ashland, KY \\
\hline AK Steel Corp & Middletown, OH \\
\hline Bethlehem Steel Corp. & Burns Harbor, IN \\
\hline Bethlehem Steel Corp. & Sparrows Point, MD \\
\hline Geneva Steel & Vineyard, UT \\
\hline Ispat Inland & East Chicago, IN \\
\hline LTV & Cleveland, OH \\
\hline LTV & East Chicago, IN \\
\hline National Steel Corp. & Ecorse, MI \\
\hline National Steel Corp & Granite City, IL \\
\hline Rouge Steel Corp. & Dearborn, MI \\
\hline US Steel Group & Braddock, PA \\
\hline US Steel Group & Fairfield, AL \\
\hline US Steel Group & Gary, IN \\
\hline Republic Technologies & Lorain, OH \\
\hline WCI Steel Inc & Warren, OH \\
\hline Weirton Steel Corp. & Weirton, WV \\
\hline $\begin{array}{l}\text { Wheeling-Pittsburgh Steel } \\
\text { Corp. }\end{array}$ & Steubenville OH \\
\hline
\end{tabular}

Most of the listed steel plants have multiple blast furnaces. Due to economic surges and declines the steel plants will "light up" or "bank" blast furnaces as needed. For calculations purposes in this study one blast furnace is always assumed to be able to accept used oil filters at the various steel plants.

\subsection{Current Operating Practice}

In North American blast furnace practice, the coke and iron ore represent about $85 \%$ of the operating costs of a net ton of hot metal (NTHM). The availability of significant quantities of relatively low priced, imported coke results in an approximate

46 "Blast Furnace Roundup," Iron and Steelmaker, Vol. 28, No. 8, August 2001, pp. 75-77. 
equal cost sharing between the iron ore and the balance of imported coke and domestic coke for the operating costs of the blast furnace.

\subsubsection{Fuel}

The dominant fuel to the blast furnace is coke. Other fuels are also utilized to both enhance productivity and also to reduce fuel cost. These include injection of pulverized coal or granulated coal, and the routine practice of heavy oil or tar injection into the hot blast at the tuyers of the blast furnace. The air blast is preheated in the blast furnace stoves to approximately $2,000^{\circ} \mathrm{F}$, to create the combustion reaction within the raceway of the blast furnace producing heat and releasing $\mathrm{CO}$ and $\mathrm{H}$ into the burden for chemical reduction.

The coke is added with the burden charging equipment to the top of the furnace and performs a vital role in maintaining a good permeability of the burden to facilitate a high volume and uniformly distributed flow of gases through the burden with a minimal pressure drop.

Besides the fuel value in the coke, the coke also provides many necessary mechanical and physical characteristics to facilitate the free flow of gases through the burden and to physically support the weight of the charge.

\subsubsection{Iron Ore}

Iron oxide pellets provide the dominant source of iron units into the blast furnace. Fluxed sinter, which may provide a means of recycling steel plant iron bearing wastes, as well as steel making slag, both contribute additional iron units to the burden.

In many blast furnace operations, it is common practice to charge metallic iron bearing scrap along with the burden into the top of the furnace. Such metallic items are normally "B" scrap derived from processing steel making slag, compressed steel turnings and/or borings, direct reduced iron products such as $\mathrm{HBI}$ and DRI.

The most likely operating candidate for consideration of used oil filters into the blast furnace would be an operation that currently has stockhouse bins allocated to the charging of metallic materials.

\subsubsection{Metallics}

The majority of the metallic output from an iron blast furnace is derived from the charging of iron ore in both lump and pellet form. Fine iron ores, and other plant waste iron oxides may be agglomerated in a sintering process. In making the ingredients for the sinter plant, additional fluxing agents may be deliberately added so as to incorporate the flux materials within the sintered iron oxide charge.

Basic oxygen steel making slag contains a sufficient quantity of metallic steel droplets contained within the slag to make recovery worthwhile. The recovery of this metal from steel making slag is often referred to as "B scrap". Depending upon 
operational characteristics at different plants, many blast furnaces routinely charge metallic $\mathrm{Fe}$ along with the iron oxide burden. Some of the metallic $\mathrm{Fe}$ is in the form of scrap metals, which have been prepared and processed so as to have high density and

free flowing characteristics for the furnace charge. The addition of metallic materials into the blast furnace usually represents a minor portion of the charge, commonly less than $20 \%$ to $2 \%$.

\subsubsection{Fluxes}

Limestone has been the traditional fluxing agent to the blast furnaces along with gravel containing silica. In some operations, the limestone and silica are substituted by fluxed sinter, fluxed pellets, or a portion of steel making slag components recycled to the blast furnace.

The charging of UOF's to the blast furnace does not appear to indicate any change to current flux practices. This is because the UOF's do not contain any appreciable quantities of either acidic or basic oxides that would offset the chemical balance of the blast furnace slag.

\subsubsection{Production}

The average production rate of USA blast furnaces is about 1.5 million tons per year each. At $90 \%$ of calendar days available for production, this would average 4,570 tons per day for a typical blast furnace.

The above-mentioned "B" scrap (metallic droplets recovered from steel making slag) is commonly utilized in a range of $40-80 \mathrm{lb} / \mathrm{NTHM}$, or about $2 \%$ to $4 \%$ of the metallic output. The study assumes a reasonable upper limit for the charging of UOF's to the blast furnace of $2 \%$, or $40 \mathrm{lb} / \mathrm{NTHM}$.

\subsubsection{Hot Metal Chemistry}

The average blast furnace would produce slag at the rate of about 4,570 NTHM/d. A typical hot metal chemistry is shown in Table $6 .^{47}$

Table 6: Hot Metal Chemistry

\begin{tabular}{|l|l|}
\hline $\mathrm{C}$ & $4.50 \%$ \\
\hline $\mathrm{Fe}$ & $94.29 \%$ \\
\hline $\mathrm{Si}$ & $0.60 \%$ \\
\hline $\mathrm{P}$ & $0.049 \%$ \\
\hline $\mathrm{Mn}$ & $0.51 \%$ \\
\hline $\mathrm{S}$ & $0.052 \%$ \\
\hline
\end{tabular}

${ }^{47}$ D. Wakelin, "The Making, Shaping, and Treating of Steel ", $11^{\text {th }}$ Edition, Ironmaking Volume, p751, AISE Steel Foundation, 1999. 


\subsubsection{Slag Chemistry}

The average blast furnace can be expected to produce about 1,020 t/day. Slag would have the approximate chemistry as shown in Table 7.

Table 7: Slag Chemistry

\begin{tabular}{|l|l|}
\hline $\mathrm{SiO}_{2}$ & $37.73 \%$ \\
\hline $\mathrm{Al}_{2} \mathrm{O}_{3}$ & $8.99 \%$ \\
\hline $\mathrm{CaO}$ & $39.73 \%$ \\
\hline $\mathrm{MgO}$ & $10.45 \%$ \\
\hline $\mathrm{MnO}$ & $0.97 \%$ \\
\hline $\mathrm{S}$ & $1.45 \%$ \\
\hline
\end{tabular}

The slag produced is generally at a rate of $450 \mathrm{lb} /$ NTHM.

\subsubsection{Gas Cleaning}

The blast furnace top gas leaves the furnace at a temperature of approximately $300^{\circ} \mathrm{F}$ to $400^{\circ} \mathrm{F}$. The gas is directed into a dust collector where in the lager particles of dust are trapped before the gas is further directed into a high intensity wet scrubber for removing the bulk of the particulate.

Any products of combustion and reduction reaction water will be condensed within the venturi scrubber at a scrubbing water temperature of approximately $80^{\circ} \mathrm{F}$.

\subsubsection{Waste Water Cleaning}

The major use of contact process water is in the scrubber system of the venturi scrubber. Approximately $3,200 \mathrm{gal} / \mathrm{NTHM}$ of water is re-circulated in the process. This water is directed first to a thickener, with $96 \%$ of water re-circulated back to the process after passing through a cooling tower or heat exchanger. Effluent water from the process of about 70 gal/NTHM goes to a wastewater treatment plant for processing to meet environmental criteria for discharge.

\subsection{Recycling of Used Oil Filters to the Blast Furnace}

At a $100 \%$ recycling rate, 122,500 tons of steel from used oil filters are available for recycling and if 19 blast furnaces are available, this would mean that each steel plant would melt 6447 tons of oil filters per year. The average annual production rate of 36 listed blast furnaces is 1.49 million tons. This average includes currently banked blast furnaces. On this basis, an average blast furnace could expect used oil filters to constitute less than $0.43 \%$ of the total hot metal output depending on yield. Based on the current $50 \%$ recycle rate, steel from used oil filters would constitute less than $0.22 \%$ of the annual hot metal output.

Averages can be misleading so perhaps it is better to look at a worst-case scenario. In the Western States recycling scenario, only one steel plant has blast 
furnaces operating west of the Mississippi River. Geneva Steel located in Vineyard, Utah has three blast furnaces but only No. 2 with an annual production rate of 1.3 million tons is listed as currently operating as of October 21, 2001. Oil filters from Hawaii, Alaska, Washington, Oregon, California (California has $12 \%$ of the total registered motor vehicles in the USA), Idaho, Nevada, Arizona, Montana, Wyoming, Colorado and New Mexico could be shipped to Geneva Steel. This would be a total of $86,739,696$ units or $19.5 \%$ of the total used filters generated in the USA each year at a $100 \%$ recycling rate. The gross weight of the filters would be 27,106 tons while the steel content would be 23,881 tons. The steel charge weight of used oil filters would constitute less than $1.84 \%$ of the annual hot metal output. At a recycling rate of $50 \%$ the steel content of used oil filters would make up less than $0.92 \%$ of the annual hot metal output.

In Table 8, the charging weights and percentages of the itemized oil filter components are calculated for an even distribution to 19 blast furnaces. A skewed distribution-charging pattern of oil filters obtained from the Western States to only one blast furnace is used as a worst-case scenario. Table 8 is based on a $50 \%$ recycling rate using current rates of oil filter generation. 
Table 8: Charging Weights and Percentages of Used Average Oil Filter Components at a $50 \%$ Recycling Rate Based on Current Oil Filter Generation Data

\begin{tabular}{|c|c|c|c|c|c|}
\hline $\begin{array}{l}\text { Oil Filter } \\
\text { Component }\end{array}$ & $\begin{array}{l}\text { Estimated } \\
\text { Unit Weight } \\
\text { per Filter } \\
\\
\text { (oz) (weight) }\end{array}$ & $\begin{array}{l}\text { Annual } \\
\text { Charging } \\
\text { Weight for } 19 \\
\text { Blast Furnaces } \\
\text { (222,564,582 } \\
\text { oil filters } \\
\text { recycled) } \\
\text { (ton) }\end{array}$ & $\begin{array}{l}\text { Annual } \\
\text { Charging } \\
\text { Percentage for } \\
19 \text { Blast } \\
\text { Furnaces at an } \\
\text { average } 1.49 \\
\text { million tons } \\
\text { apiece } \\
(\%)\end{array}$ & $\begin{array}{l}\text { Annual } \\
\text { Charging } \\
\text { Weight for } \\
\text { Western States } \\
\text { Scenario } \\
(43,369,848 \text { oil } \\
\text { filters } \\
\text { recycled) } \\
\text { (ton) }\end{array}$ & $\begin{array}{l}\text { Annual } \\
\text { Charging } \\
\text { Percentage for } \\
\text { Western States } \\
\text { Scenario, One } \\
\text { Blast Furnace } \\
\text { at } 1.3 \text { million } \\
\text { tons } \\
(\%)\end{array}$ \\
\hline Can & 3.48 & 24204 & 0.0855 & 4716 & 0.3628 \\
\hline Base Plate & 2.94 & 20448 & 0.0722 & 3985 & 0.3065 \\
\hline Center Tube & 0.98 & 6816 & 0.0241 & 1328 & 0.1022 \\
\hline $\begin{array}{l}\text { Top/Bottom } \\
\text { Plates }\end{array}$ & 0.87 & 6051 & 0.0214 & 1179 & 0.0907 \\
\hline Springs & 0.54 & 3756 & 0.0133 & 732 & 0.0563 \\
\hline $\begin{array}{l}\text { Total Steel } \\
\text { Components }\end{array}$ & 8.81 & 61275 & 0.2164 & 11940 & 0.9185 \\
\hline $\begin{array}{l}\text { Tin Content if } \\
\text { Present }^{48}\end{array}$ & 0.03 & 209 & 0.0007 & 41 & 0.0031 \\
\hline $\begin{array}{l}\text { Minimum Zinc } \\
\text { Content if } \\
\text { Present } \\
\end{array}$ & 0.059 & 410 & 0.0014 & 80 & 0.0062 \\
\hline Filter Media & 1.74 & 12102 & 0.0427 & 2358 & 0.1814 \\
\hline Rubber & 0.34 & 2365 & 0.0084 & 461 & 0.0354 \\
\hline Assembled Filter & 10.89 & 75742 & 0.2675 & 14759 & 1.1353 \\
\hline Oil-Full & 14.69 & 102157 & 0.3609 & 19907 & 1.5313 \\
\hline $\begin{array}{l}\text { Oil -Improperly } \\
\text { Drained }\end{array}$ & 10.27 & 71443 & 0.2524 & 13922 & 1.0709 \\
\hline $\begin{array}{l}\text { Oil-Properly Hot } \\
\text { Drained }\end{array}$ & 5.87 & 40841 & 0.1443 & 7958 & 0.6122 \\
\hline $\begin{array}{l}\text { Oil-Drained and } \\
\text { Crushed }\end{array}$ & 1.74 & 12130 & 0.0428 & 2364 & 0.1818 \\
\hline
\end{tabular}

Table 9 utilizes a predicted $70 \%$ recycling rate based on a compounded $1 \%$ annual increase in new oil filter sales and a $5 \%$ yearly increase in the recycling rate between 2001 to the end of 2005 .

48 Assumed $0.030 \% \mathrm{Sn}$ in melted steel components, which exhibited a $76 \%$ metallic yield. 
Table 9: Charging Weights and Percentages of Used Average Oil Filter Components at a $70 \%$ Recycling Rate Based on Future Growth

\begin{tabular}{|c|c|c|c|c|c|}
\hline $\begin{array}{l}\text { Oil Filter } \\
\text { Component }\end{array}$ & $\begin{array}{l}\text { Estimated Unit } \\
\text { Weight per } \\
\text { Filter } \\
\text { (oz) (weight) }\end{array}$ & $\begin{array}{l}\text { Annual } \\
\text { Charging } \\
\text { Weight for } 19 \\
\text { Blast Furnaces } \\
\text { (320,506,035 } \\
\text { oil filters } \\
\text { recycled) } \\
\text { (ton) }\end{array}$ & $\begin{array}{l}\text { Annual } \\
\text { Charging } \\
\text { Percentage for } \\
19 \text { Blast } \\
\text { Furnaces at an } \\
\text { average } 1.49 \\
\text { million tons } \\
\text { apiece } \\
(\%)\end{array}$ & $\begin{array}{l}\text { Annual } \\
\text { Charging } \\
\text { Weight for } \\
\text { Western States } \\
\text { Scenario } \\
(63,183,173 \text { oil } \\
\text { filters } \\
\text { recycled) } \\
\text { (ton) }\end{array}$ & $\begin{array}{l}\text { Annual } \\
\text { Charging } \\
\text { Percentage for } \\
\text { Western States } \\
\text { Scenario, One } \\
\text { Blast Furnace } \\
\text { at } 1.3 \text { million } \\
\text { tons } \\
(\%)\end{array}$ \\
\hline Can & 3.48 & 34855 & 0.1231 & 6871 & 0.5286 \\
\hline Base Plate & 2.94 & 29446 & 0.1040 & 5805 & 0.4465 \\
\hline Center Tube & 0.98 & 9815 & 0.0347 & 1935 & 0.1488 \\
\hline $\begin{array}{l}\text { Top/Bottom } \\
\text { Plates }\end{array}$ & 0.87 & 8714 & 0.0308 & 1718 & 0.1321 \\
\hline Springs & 0.54 & 5409 & 0.0191 & 1066 & 0.0820 \\
\hline $\begin{array}{l}\text { Total Steel } \\
\text { Components }\end{array}$ & 8.81 & 88239 & 0.3117 & 17395 & 1.3381 \\
\hline $\begin{array}{l}\text { Tin Content if } \\
\text { Present }^{49}\end{array}$ & 0.03 & 300 & 0.0011 & 59 & 0.0046 \\
\hline $\begin{array}{l}\text { Minimum Zinc } \\
\text { Content if } \\
\text { Present }\end{array}$ & 0.059 & 591 & 0.0021 & 116 & 0.0090 \\
\hline Filter Media & 1.74 & 17428 & 0.0616 & 3436 & 0.2643 \\
\hline Rubber & 0.34 & 3405 & 0.0120 & 671 & 0.0516 \\
\hline $\begin{array}{l}\text { Assembled } \\
\text { Filter }\end{array}$ & 10.89 & 109072 & 0.3853 & 21502 & 1.6540 \\
\hline Oil-Full & 14.69 & 147112 & 0.5196 & 29001 & 2.2309 \\
\hline $\begin{array}{l}\text { Oil-Improperly } \\
\text { Drained }\end{array}$ & 10.27 & 102882 & 0.3634 & 20282 & 1.5601 \\
\hline $\begin{array}{l}\text { Oil-Properly } \\
\text { Hot Drained }\end{array}$ & 5.87 & 58813 & 0.2077 & 11594 & 0.8919 \\
\hline $\begin{array}{l}\text { Oil-Drained } \\
\text { and Crushed }\end{array}$ & 1.74 & 17468 & 0.0617 & 3443 & 0.2649 \\
\hline
\end{tabular}

The writers recognize that it is not cost effective to consider shipping oil filters from remote distances to a blast furnace, unless economic incentives are provided to facilitate overcoming the transportation cost disadvantage. The major advantage for blast furnace operators using UOF's would be the low cost of quality iron units.

A further review of geographic availability of UOF's has been calculated for an Indiana/Chicago blast furnace and a Pittsburgh/Youngstown regional blast furnace. For the Indiana/Chicago region, the availability of UOF's from lowa, Illinois, Indiana, Michigan, and Wisconsin would equal 31.2 million UOF's. The yield calculation of steel at this collection rate would equal 12,300 tons, which divided by an average blast furnace size of $1.5 \mathrm{Mtpy}$ would equal $0.82 \%$ of the charge, or $16 \mathrm{lbs}$ UOF/NTHM. The Indiana/Chicago region is the AISI designation for steel plants in that area.

49 Assumed $0.030 \%$ Sn in melted steel components, which exhibited a $76 \%$ metallic yield. 
In a similar fashion, a consideration for states adjoining a Pittsburgh/Youngstown regional blast furnace would include Connecticut, Ohio, Delaware, Maryland, New York, New Jersey, and Pennsylvania; for a total of 43.5 million UOF's. The calculation again would indicate a total of 17,100 tons of UOF's for an average 1.5 Mtpy blast furnace. This would be a charging rate of $1.1 \%$ of the burden or $23 \mathrm{lb}$ UOF/NTHM.

\subsubsection{Material Handling and Storage}

The typical blast furnace requires approximately 2 tons of solid charged materials for each net ton of hot metal (NTHM) produced. A nominal blast furnace operation will handle $9,000 \mathrm{t} /$ day of bulk materials.

The blast furnace raw materials are normally delivered to the site in railroad cars which are then unloaded either directly into material bins by bottom discharge, or through a series of conveyor belt transfer into the blast furnace stockhouse bins.

The potential recycling of used automotive filters into the blast furnace will require that the UOF's be compatible with the overall bulk material handling system. This includes factors such as free flowing through gates and bins, sizing compatible with bin flow and gate control devices, screens, and sufficient density to avoid being removed from the top of the furnace by the velocity of the top gases.

A major consideration is the degree to which oil may be discharged from used oil filters while being stored in bins prior to entering the furnace. Any oil that may leak from the filters into the bin poses a potential problem of dripping from the bottom of the bins (which are only designed to contain solids, not liquids) and may find its way into the drainage system beneath the stockhouse. This would create additional problems of wastewater treatment to remove any contained used motor oil from the drainage collection system.

Communications between buyers and suppliers of UOF's in the supply chain should be able to properly address any concerns over freely draining oil.

\subsubsection{Size Requirements}

The blast furnace material handling systems can accommodate maximum particle sizes up to about 6 in $\times 6$ in. However, the actual size of materials charged must be carefully considered with respect to the sizing of other materials on the burden. This sizing requirement is essential to maintain good burden permeability for the free flow of process gasses through the burden. Discussions with blast furnace operators have indicated that the preferred maximum size for scrap materials would be represented by approximately 2 in $\times 3$ in or the pressed form of scrap known as "hockey puck" of about 3 in $x 4$ in diameter.

UOF's, which have been properly drained, still contain about $40 \%$ by weight motor oil. Additionally the low bulk density at about $16.3 \mathrm{lb} / \mathrm{ft}^{3}$ would occupy excessive volume in the skip-charging car to the furnace. Excess oil leaking from the filters would cause significant oil contamination problems in the material handling system. 
The properly drained and crushed UOF's would represent the least cost processing for recycling to the blast furnace, although it still contains approximately $13 \%$ oil in the filter media. Further observation will be required to see whether or not such crushed and drained UOF's would continue to leak amounts of oil that would considered excessive by the blast furnace operator.

UOF's, which have been shredded and the non-metallic materials removed, would have oil content of less than $2 \%$ (mainly surface adhering oil) but would be too low in density to remain within the furnace due to the high top gas velocity. Additional compressing of shredded oil filter metallics would be required to achieve the density necessary for blast furnace operations, although this entails additional processing costs.

\subsubsection{Effect on Blast Furnace Process}

As previously discussed, due to regional availability and materials blending requirements, it is expected that approximately $2 \%$ maximum of the burden (40 $\mathrm{lb} / \mathrm{NTHM}$ ) would be the most likely rate to be considered. Some blast furnace operators routinely charge as much as $200 \mathrm{lb} /$ ton of high quality iron units in the form of HBI (Hot Briquetted Iron). The actual charging rate for UOF's would need to be arrived at in discussions with potential operators of the blast furnace.

\subsubsection{The Chemistry of Motor Oil in the Blast Furnace}

This feasibility study for recycling used oil filters in the iron blast furnace was based upon two main factors: the recovery of iron units from the steel container, and the potential recovery of energy from the contained motor oil. The only fuel routinely added to the top of a blast furnace is coke. Coke, as a result of the pyrolysis of coal in coke oven plants, does not have any appreciable remaining volatility. Other fuels used in the blast furnace include tar, fuel oil, granulated and pulverized coal, and natural gas: all of which are injected along with the hot blast through the tuyeres.

No references could be found regarding previous charging of oil or other hydrocarbons into the top of an iron blast furnace. The writers have constructed a schematic representation of the blast furnace indicating probable time, temperature and gas composition relationships based upon their own calculations and some references in the literature as shown in Figure $2 .^{50} 51$

Also shown in Figure 2, the box shape, which represents a UOF, entering the top of the furnace, undergoing pyrolysis, and ultimately melting into the liquid iron bath at around 7 hours schematically represents the position of used oil filters in the blast furnace as a function of time.

\footnotetext{
${ }^{50} \mathrm{R}$. Jeschar, A Theoretical Model Coupling Kinetics of Ore Reduction and Coke Gasification in Cocurrent and Countercurrent Reactors, Fifth International Iron and Steel Congress, Washington, April 6-9, p 992, Iron \& Steel Society, 1986.

${ }^{51}$ A. Poos, and N. Pongjis, 1994 Turkdogan Symposium Proceedings, Application of Process Models for the design of an Optimized Blast Furnace Process, p 45, Iron \& Steel Society, 1994.
} 


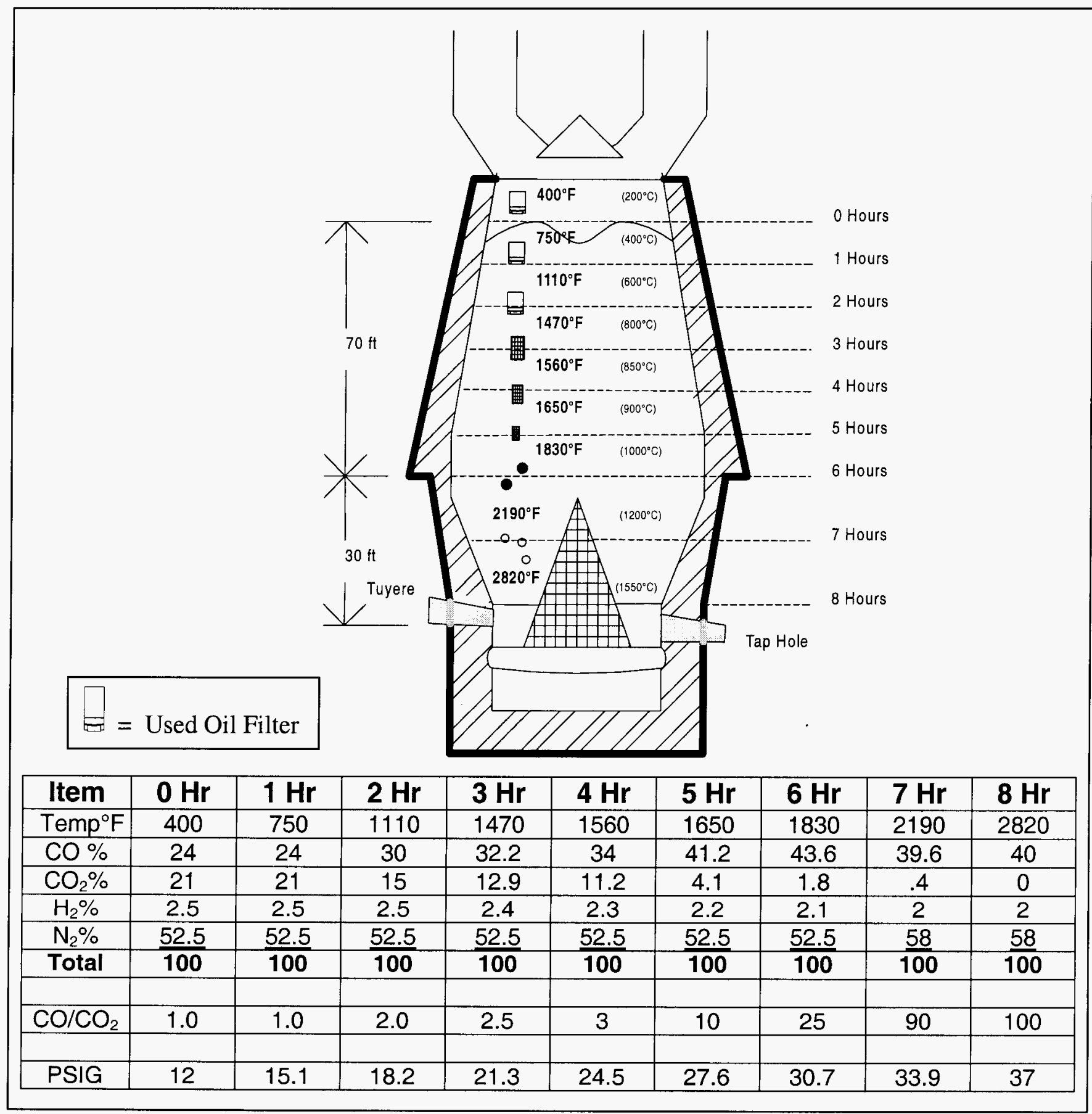

Figure 2: Schematic representation of blast furnace time and temperature relationships, approximate. 


\subsection{Composition and Properties of Motor Oil}

Fresh Motor Oils typically contain $\mathrm{C}_{18}$ to $\mathrm{C}_{32}$ paraffinic, napthenic and aromatic hydrocarbons with boiling points starting around $620{ }^{\circ} \mathrm{F} .{ }^{52}$ The ingredients of three different brands of motor oil are given in Table 10.

Table 10: Ingredients of Fresh Motor Oil ${ }^{53}$

\begin{tabular}{|l|c|l|}
\hline Brand & Weight \% Range & Ingredients \\
\hline Havoline Motor & $75-94.99$ & Hydro treated heavy paraffinic distillate \\
Oil & $3-8.99$ & Solvent refined hydro treated middle distillate \\
10 -30 & $<1$ & Proprietary Additives \\
\hline Quaker State HD & $<90$ & Hydro treated heavy paraffinic distillate \\
SAE Motor Oil & $<90$ & Solvent-dewaxed heavy paraffinic distillate \\
All Grades & $10-20$ & Detergent/Inhibitor system \\
& $<1$ & Pour point depressant \\
\hline Pennzoil Multi- & $75-80$ & Base Lubricating Oils \\
Grade Motor Oil & $5-15$ & Detergent/Inhibitor system \\
All Grades & $5-15$ & Viscosity index improver \\
& $<1$ & Pour point depressant \\
& $<1$ & Antifoam Additive \\
\hline
\end{tabular}

Table 10 shows that fresh motor oil consists of primarily paraffins, which are noncyclic, saturated hydrocarbons. The effects of additives were not considered in this study since they make up a small percentage of the oil.

An analysis of the composition of used motor oil is shown in Table 11. Used Motor Oils contain heavy polycyclic aromatic hydrocarbons (PAHs), which are aromatics with two or more rings. The structure of some of the PAHs is shown in Appendix 7.

Some PAHs are known carcinogens although for many others the effects are not determined. Shown in Table 12, is the concentration of various PAHs found in a sample of motor oil. The total PAH concentration in this sample is low, $0.17 \%$, and most of the PAHs have high boiling points, and so will remain in the furnace until they have broken down. Table 13 shows the metal content of used oil, and Table 14 shows the nitrogen and sulfur content.

The chemistry of used motor oil is highly variable. To assist the reader in this regard, Table 15: Compositions of Used Oil and Other Fuels, has been partially reproduced to illustrate a sampling of Virgin Lube, Used Gasoline Engine Oil, and Used Diesel Engine Oil.

\footnotetext{
${ }^{52}$ Robert A. Meyers. Environmental Analysis and Remediation, v. 6. John Wiley \& Sons, New York, 1998. p. 3669

${ }^{53}$ Internet
} 
The time of acquisition of used motor oil samples for chemical analysis that is referenced in a later section is not known. Although the early references to toxicology of used motor oil make an inferred relationship to studies involving fresh water trout species and PAH's compounds (polycyclic aromatic hydrocarbons), the very high lead content may also be a toxicity factor. This is discussed in section 4.3.3.1.1, composition of properties in motor oil.

The lead content shown in Table 15 at $47.2 \mathrm{ppm}$ to $57 \mathrm{ppm}$ is markedly lower than that shown in

Table 13 at $18500 \mathrm{ppm}$ (1.85\%). A possible explanation may be associated with the phase out of leaded gasoline for non-leaded gasoline and its effect on used motor oil samples for chemical analysis before this transition.

Table 11: Hydrocarbon Group Analysis of used motor oil ${ }^{54}$.

\begin{tabular}{|l|l|}
\hline Hydrocarbon Group & Weight \% \\
\hline Saturates & $76.6-86.3$ \\
\hline Aromatics & $4.1-12.9$ \\
\hline Polars & $0.8-3.8$ \\
\hline Asphaltenes & 0 \\
\hline Volatiles & 3.2 \\
\hline
\end{tabular}

\footnotetext{
${ }^{55}$ Irwin, Roy J. et al. Environmental Contaminants Encyclopedia, Used Motor Oil Entry. National Park Service, 1997. http://nature.nps.gov/toxic/oilused.pdf.
} 
Table 12: Concentrations of PAHs found in one sample of motor oil ${ }^{55}$

\begin{tabular}{|l|l|}
\hline Compound & Conc. (ppm) \\
\hline Low molecular weight PAHS & \\
\hline - Naphthalene & 52.0 \\
\hline - Acenapthylene & 1.5 \\
\hline - Acenapthene & 3.7 \\
\hline - Fluorene & 67.0 \\
\hline - Phenanthrene & 200.0 \\
\hline - Anthracene & 22.0 \\
\hline High Molecular Weight PAHs & \\
\hline - Fluoranthene & 55.0 \\
\hline - Pyrene & 120.0 \\
\hline - Benz(a)anthracene & 38.0 \\
\hline - Chrysene & 45.0 \\
\hline - Benzofluoranthenes & 46.0 \\
\hline - Benzo(e)pyrene & 32.0 \\
\hline - Benzo(a)pyrene & 15.0 \\
\hline - Perylene & 1.1 \\
\hline - Indo(1,2,3-cd)pyrene & 14.0 \\
\hline - Dibenz(ah)anthracene & 1.5 \\
\hline - Benzo(ghi)perylene & 72.0 \\
\hline Alkylated PAHs & \\
\hline - C-1 naphthalene & 31.0 \\
\hline - C-2 naphthalene & 60.0 \\
\hline - C-3 naphthalene & 80.0 \\
\hline - C-4 naphthalene & 52.0 \\
\hline - C-1 phenanthrene & 300.0 \\
\hline - C-2 phenanthrene & 300.0 \\
\hline - C-3 phenanthrene & 140.0 \\
\hline - C-4 phenanthrene & 35.0 \\
\hline Total PAH concentration & 1783 \\
\hline
\end{tabular}


Table 13: Metal Content of Used Oil ${ }^{54}$

\begin{tabular}{|l|l|}
\hline Component & Conc. (ppm) \\
\hline Aluminum & 15 \\
\hline Copper & 18 \\
\hline Iron & 220 \\
\hline Lead & 18500 \\
\hline Silicon & 17 \\
\hline Antimony & 6 \\
\hline Sodium & 59 \\
\hline Calcium & 688 \\
\hline Barium & 177 \\
\hline Zinc & 1360 \\
\hline Magnesium & 410 \\
\hline
\end{tabular}

Table 14: Non-Metal Inorganic Content of Used $\mathrm{Oil}^{54}$

\begin{tabular}{|l|l|}
\hline Component & Conc. (wt \%) \\
\hline Nitrogen & 0.09 \\
\hline Sulfur & $0.29-0.54$ \\
\hline
\end{tabular}

Table 15: Compositions of Used Oil and Other Fuels ${ }^{55}$

\begin{tabular}{|l|c|c|c|}
\hline \multicolumn{1}{|c|}{ Component } & $\begin{array}{c}\text { Used Gasoline } \\
\text { Engine Oil }^{\mathrm{a}}\end{array}$ & $\begin{array}{c}\text { Used Diesel } \\
\text { Engine Oil }^{\mathrm{a}}\end{array}$ & Virgin Lube $^{\mathrm{a}}$ \\
\hline Ash, wt\% & 0.54 & 0.46 & 0.14 \\
\hline Sulfur, wt\% & 0.36 & 0.25 & 0.36 \\
\hline Nitrogen, wt\% & 0.04 & 0.02 & 0.02 \\
\hline Barium, ppm & 2.7 & 3.4 & $<1.0$ \\
\hline Beryllium, ppm & $<0.02$ & $<0.02$ & $<0.02$ \\
\hline Cadmium, ppm & 1.5 & 2.4 & $<0.25$ \\
\hline Chromium, ppm & 3.2 & 3.9 & $<2$ \\
\hline Lead,ppm & 47.2 & 57 & $<20$ \\
\hline Nickel, ppm & 1 & 1.8 & $<1.2$ \\
\hline Zinc, ppm & 1,162 & 1,114 & $<200$ \\
\hline Halogens, ppm & 350 & 234 & $<20$ \\
\hline
\end{tabular}

${ }^{55}$ D.J. Graziano and E.J. Daniels, Assessment of Opportunities to Increase the Recovery and Recycling Rates of Waste Oils. Energy Systems Division Argonne National Laboratory, Contract W-31-109-Eng-38, for the United States Department of Energy, pg 54, August 1995. 


\subsection{Distillation of Oil in the Blast Furnace}

With the use of the thermal profile and the pressure profile given in Figure 2, flash calculations for the distillation of the oil, as in Appendix 4, were performed to calculate the vapor-liquid equilibrium properties of the oil in each temperature section.

The NIST Chemistry Web Book ${ }^{56}$ provided Antoine Equation ${ }^{57}$ parameters for calculating saturated pressure. Table 16 lists the Antoine equation parameters available for various paraffins and pyrene. Since Antoine parameters were only available for the paraffins listed, the flash calculations were done using only these components plus pyrene since it is a PAH that is reported to have a higher concentration. The calculation using only these components should give an adequate understanding since the boiling points should be similar.

Table 16: Antoine parameters for various hydrocarbons (Appendix 4: eq.2)

\begin{tabular}{|l|c|c|c|}
\hline \multicolumn{1}{|c|}{ Species } & A & B & C \\
\hline $\mathrm{C}_{18} \mathrm{H}_{38}$ & 4.332 & 2068.96 & -111.927 \\
\hline $\mathrm{C}_{21} \mathrm{H}_{44}$ & 5.92073 & 3571.218 & -19.953 \\
\hline $\mathrm{C}_{23} \mathrm{H}_{48}$ & 6.557 & 4200.069 & 1.864 \\
\hline $\mathrm{C}_{26} \mathrm{H}_{54}$ & 6.5763 & 4224.36 & -30.387 \\
\hline $\mathrm{C}_{27} \mathrm{H}_{56}$ & 6.256 & 3654.27 & -86.045 \\
\hline Pyrene & 2.68713 & 1086.824 & -262.849 \\
\hline
\end{tabular}

Flash Calculations show that at 0 hours and $400^{\circ} \mathrm{F}$, all of the oil will be in liquid form, at 1 hour and $750^{\circ} \mathrm{F}, 99.8 \%$ of the oil will be vaporized and $0.2 \%$ of the oil will be in liquid form and go down to the next stage during hour 2. At that point the remaining oil will then be vaporized. Therefore the oil will remain in the 1-hour stage until it has decomposed into products with boiling points below $400^{\circ} \mathrm{F}$, which would include hydrocarbons with 11 or less Carbons, or it will react to form products that act as petroleum coke. The products of these reactions will be discussed further in the next section.

\subsection{Reactions of Oil in the Blast Furnace}

When petroleum fractions are heated to temperatures over $660^{\circ} \mathrm{F}$, thermal decomposition will proceed at significant rates. ${ }^{58}$ Paraffins have the least thermal stability and very severe thermal cracking of heavy hydrocarbons can result in condensation reactions of ring compounds, yielding a high fraction of coke. ${ }^{58}$ Thermal decomposition, which is also referred to as cracking or pyrolysis, involves free radical reactions consisting of the following steps: (1) Initiation - the introduction of free radicals

56 "NIST Chemistry Web Book",

"http://WebBook.nist.gov/cgi/cbook.cgi?ID=C593453\&Units=SI\&Mask=4.".

${ }^{57}$ J.M. Smith and H.C. Van Ness. "Introduction to Chemical Engineering Thermodynamics". McGrawHill, Inc. New York, 1987.

${ }^{58}$ James Speight. The Chemistry and Technology of Petroleum $3^{\text {rd }}$ ed. Marcel Dekker, Inc., New York, 1999. 
into the system which typically involves the cleavage of a C-C bond in heavy paraffins. (2) Propagation - a series of reactions that converts reactants to products while leaving the radical concentrations unchanged. (3) Termination - the combination of radicals to give stable products. ${ }^{59}$

The primary reactions that occur during free radical reactions of hydrocarbons are decomposition reactions such as: ${ }^{58}$

$$
\mathrm{CH}_{3}-\mathrm{CH}_{2}-\mathrm{CH}_{2}-\mathrm{CH}_{3} \longrightarrow \mathrm{CH}_{3}-\mathrm{CH}=\mathrm{CH}_{2}+\mathrm{CH}_{4} \text {. }
$$

The secondary reactions are those where the primary product form higher molecular weight products, i.e.: ${ }^{58}$

$$
\mathrm{CH}_{2}=\mathrm{CH}_{2}+\mathrm{CH}_{2}=\mathrm{CH}_{2} \longrightarrow \mathrm{CH}_{3} \mathrm{CH}_{2} \mathrm{CH}=\mathrm{CH}_{2} \text {, }
$$

or

$$
\mathrm{R}-\mathrm{CH}=\mathrm{CH}_{2}+\mathrm{R}^{\prime}-\mathrm{CH}=\mathrm{CH}_{2} \longrightarrow \text { Cracked Residuum }+ \text { coke }+ \text { other products } .
$$

Table 17 lists experimental results of pyrolysis of partially hydrogenated gas oil, which is the closest available comparison to used motor oil as far as molecular weight, composition and boiling point range, although the motor oils would contain a higher percentage of paraffins.

Table 17: Results of the pyrolysis of partially hydrogenated gas oil with a temperature profile between $1292-1526^{\circ} F^{60}$

\begin{tabular}{|l|c|}
\hline Reaction Products & $\begin{array}{l}\text { Wt \% related } \\
\text { to feed }\end{array}$ \\
\hline Cracked gas $\leq \mathrm{C} 4$ & 62 \\
\hline Pyrolysis gasoline $\left(\mathrm{C}_{5}\right.$ to $\left.\mathrm{T}_{\text {boil }}<392^{\circ} \mathrm{F}\right)$ & 27.7 \\
\hline Pyrolysis Fuel Oil $\left(\mathrm{T}_{\text {boil }} \geq 392^{\circ} \mathrm{F}\right)$ & 9.0 \\
\hline Coke and Tar & 0.9 \\
\hline
\end{tabular}

Figure 3 outlines the results given in Table 17, and shows the final destination of the products. About $90 \%$ of the products would have boiling points below $400^{\circ} \mathrm{F}$ and would therefore leave the top of the furnace. Of this, about $28 \mathrm{wt} \%$ of the feed (gasoline fraction) will condense in the scrubber at $80^{\circ} \mathrm{F}$ and $62 \%$ (Gas fraction) is not condensable at that temperature and will be used as fuel gas. The gasoline fraction contains $9 \mathrm{wt} \%$ (of the feed) oil as benzene and toluene. Benzene is considered toxic in exposure levels above $25 \mathrm{ppm}$ for an 8 hour shift, and toluene above $300 \mathrm{ppm}$.

Benzene has been identified as a carcinogen. The remaining products consist of $9 \mathrm{wt} \%$ (of the feed) of fuel oil with $t_{\text {boil }}>392^{\circ} \mathrm{F}$ and $0.9 \mathrm{wt} \%$ of coke. The fuel oil should undergo

\footnotetext{
${ }^{59}$ Lyle F. Albright, et al. Pyrolysis: Theory and Industrial Practice. Academic Press, New York, 1983. Iron can act as a catalyst to produce surface carbon. ${ }^{6}$

${ }^{60}$ Nowak et al. Chem Tech. v. 31 p. 496-500, 1979.
} 
further cracking to form more volatile products and coke. The deposit of coke may contain high boiling point PAHs in the form of tars, and ordered or disordered carbon, formed in the gas phase or on a surface. Any such PAH in the coke will be destroyed in the high temperature zones of the process. Iron can act as a catalyst to produce surface carbon.

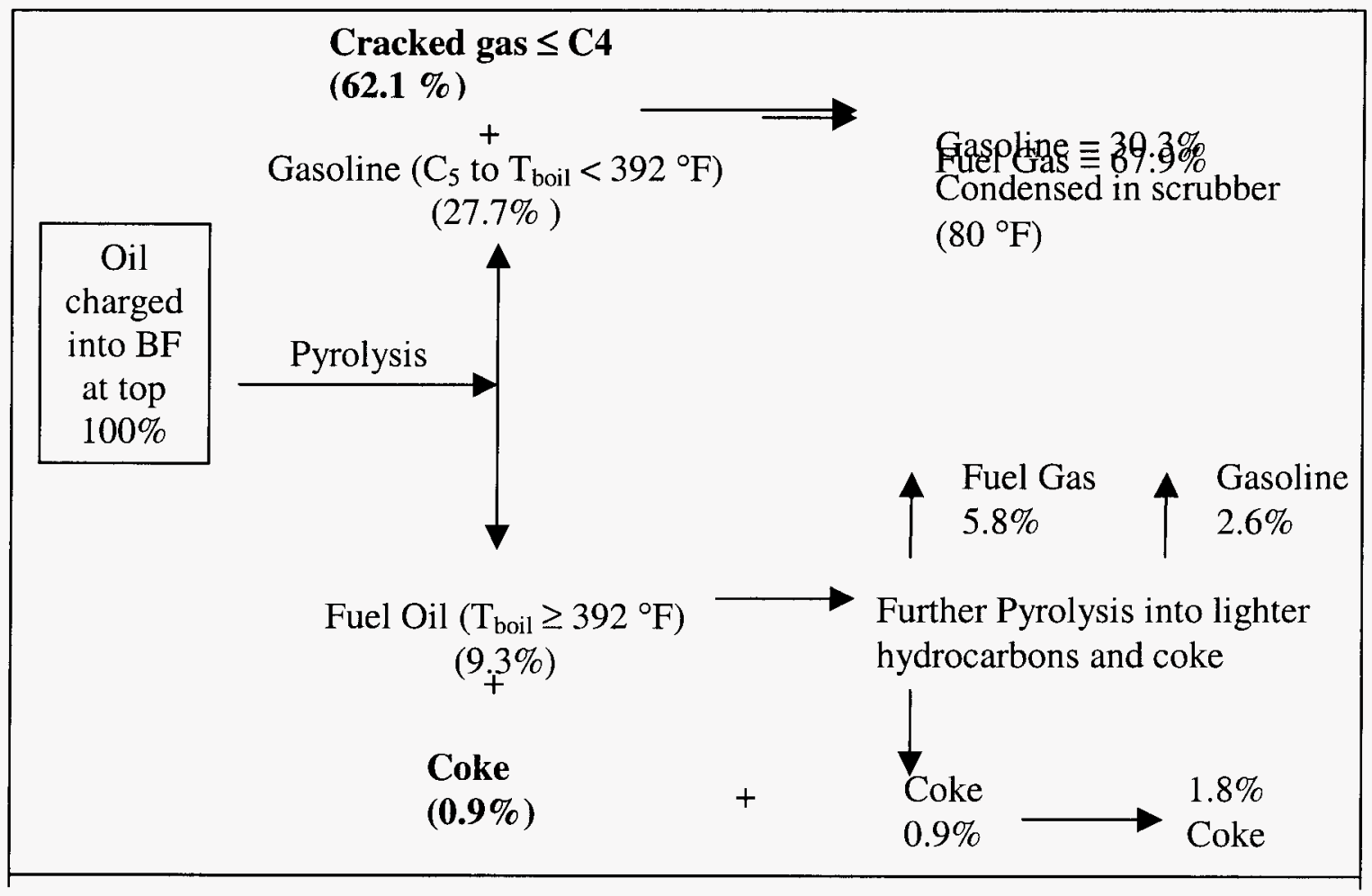

Figure 3: Flow diagram outlining the pyrolysis of Gas Oil shown in Table 15

Figure 4 outlines the production of coke in the pyrolysis of hydrocarbons. The hydrocarbons are first broken down into lighter hydrocarbons and heavier hydrocarbons. The lighter hydrocarbons can be further decomposed to gases. The heavier hydrocarbons can undergo polymerization to form high molecular weight hydrocarbons which then react to form carbon and tar. Many of the PAHs should form coke ${ }^{61}$.

During the pyrolysis reactions, the $9.3 \%$ of pyrolyzed fuel oil in the burden at 1 hour will undergo further pyrolysis into lighter hydrocarbons and coke, approximating a distribution of $5.8 \%$ as fuel gas, $2.6 \%$ as gasoline, and $0.9 \%$ as additional coke.

The calculations indicate that for $100 \%$ of the weight of used oil charged into the top of the blast furnace into the burden, all of the oil will remain as a liquid until reaching the 1 -hour zone of about $750^{\circ} \mathrm{F}$. Within the burden at this temperature zone, about $90 \%$ of the charged oil will vaporize, undergo pyrolysis and exit the blast furnace with the top

\footnotetext{
${ }^{61}$ G.F. Froment, Coke formation in the thermal cracking of hydrocarbons. Reviews in Chemical Engineering. V. 6, n4, p293-328, 1990.
} 
gas. The overall result of charging oil into the top of the blast furnace is decomposed as follows:

$\begin{array}{ll}\text { Oil Input } & =100.0 \% \\ \text { Fuel Gas } & =67.9 \% \\ \text { Condensate (Gasoline) } & =30.3 \% \\ \text { Coke } & =1.8 \%\end{array}$

The heavier hydrocarbon oils with 12 or more carbons, about $10 \%$, will undergo progressive pyrolysis in the lower and higher temperature zones of the burden until lighter hydrocarbons leave the top of the burden and the heavier hydrocarbons are converted to coke, at about $2 \%$ of the oil charge weight.

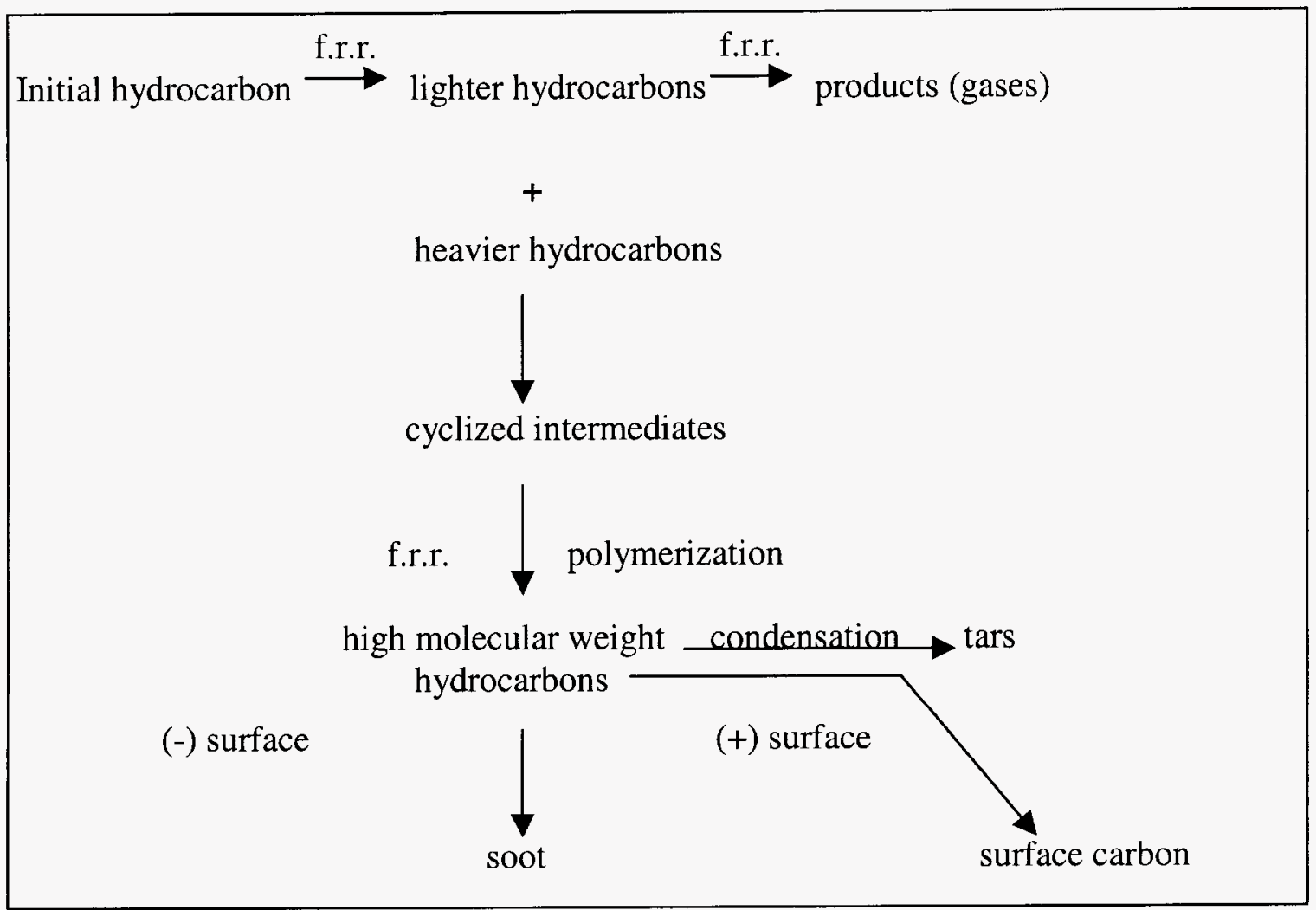

Figure 4: Flow Diagram for the production of coke. Any hydrocarbon can yield catalytic carbon in the presence of some materials. (f.r.r. = Free-radical reactions) ${ }^{59}$

\subsubsection{Fuel Value Recovered}

Table 18 represents calculated values for the composition of the products of pyrolysis of used motor oil in the blast furnace. The weight distribution of the components of the major products is an approximation used by the writers based on the best available information and calculations. Although the actual weight percentages in 
the final products of the pyrolysis reaction are very small, it was felt that it might be useful to future work, or analysis of greater concentrations of oil input to the blast furnace to provide a comprehensive review of the pyrolysis products.

The calculations in Table 18 were utilized to obtain an average molecular weight for fuel gas and the "gasoline" fraction. For the case illustrated at a $2 \%$ charge of UOF's to the burden, the fuel gas weighing $7 \mathrm{lb}$ would occupy $71 \mathrm{sct}$ at a molecular weight of 35.7 lb. In a similar calculation, the gasoline fraction that will condense at a weight of $3 \mathrm{lb}$ would occupy a volume of $10.5 \mathrm{scf}$ in the gas phase at a molecular weight of $102.8 \mathrm{lb}$. These values are shown in the material balance of Figure 6.

Table 18: Calculated results of the composition of the products of pyrolysis of used motor oil to obtain average molecular weights

\begin{tabular}{|l|l|l|l|l|}
\hline \multicolumn{1}{|c|}{ Products } & \multicolumn{1}{c|}{ Wt \%ol. Wt. } & Product Fraction & Mol. Wt. Fraction \\
\hline Propylene & & & & \\
\hline Ethylene & 15.3 & 42.1 & 0.225 & 9.5 \\
\hline Butadiene & 27.4 & 28.1 & 0.404 & 11.4 \\
\hline C1 to C4 (avg.) & 2.4 & 54.1 & 0.065 & 3.5 \\
\hline Fuel Gas & 67.9 & 37.0 & 0.306 & 11.3 \\
\hline Avg. Mol. Wt. & & & & \\
\hline & & & & 35.7 \\
\hline Benzene & 4.4 & & & \\
\hline Toluene & 4.4 & 78.1 & 0.145 & 11.3 \\
\hline C5 to C10 (avg.) & 21.5 & 92.1 & 0.145 & 13.3 \\
\hline Gasoline & 30.3 & 110.2 & 0.710 & $\underline{78.2}$ \\
\hline Avg. Mol. Wt. & & & & 102.8 \\
\hline & & & & \\
\hline Coke & & & & 12 \\
\hline Carbon & 1.8 & & 1.00 & \\
\hline Input Motor Oil & 100.0 & 12 & & \\
\hline
\end{tabular}

As a simplifying assumption, the authors have chosen to equate the heating value of the fuel gas equivalent to methane $\left(\mathrm{CH}_{4}\right)$ with a heating value of $1,000 \mathrm{Btu} / \mathrm{Ft}^{3}$.

\subsubsection{Top Gas Chemistry}

Because of the very small contribution to the total gas volume made by the fuel gas, which is equivalent to 1.2 weight\% of the total top gas volume, it is not felt to be practical to develop a detailed chemistry for the overall top gas.

\subsubsection{Metallics Recovered}

Metallics ( $\mathrm{Fe}$ ) will be recovered at a rate of nearly $100 \%$ of the $\mathrm{Fe}$ in the charged materials. Therefore the metallics recovered from UOF's would be equal to the weight fraction of $\mathrm{Fe}$ in the weight of the UOF. For the drained and crushed UOF in the illustrated case, a value of $76 \%$ of the weight of the UOF is indicated. ${ }^{1}$ 


\subsubsection{Slag Chemistry}

There is no quantifiable change in slag chemistry as there are virtually no oxide minerals present in the UOF's.

\subsubsection{Hot Metal Chemistry}

As mention in section 3.3.2 Steel Coatings, coated steels are used in oil filters. Steel provided to the manufacturer of oil filters is approximated by $50 \%$ uncoated, $25 \%$ galvanized (zinc coated) and $25 \%$ tin plate. An earlier study referenced in this same section showed an analysis on melting a charge of $100 \%$ UOF's resulting in a residual tin level from 0.026 to 0.035 weight \%. However, it is not presently known if this represents a mixture of both coated and uncoated filters.

Therefore a $40 \mathrm{lb}$ UOF/t burden charge at a $76 \%$ metallic yield would result in $34.4 \mathrm{lb}$ Fe/NTHM. This $30.4 \mathrm{lb}$ of Fe derived from the UOF would contain $0.008 \mathrm{lb} /$ tin $(\mathrm{Sn})$. This gives a calculated increase to the tin content of the hot metal of $0.04 \mathrm{ppm}$, an insignificant amount. To summarize, the effect of adding UOF's to the BF burden at a charging rate of $40 \mathrm{lb}$ UOF/NTHM results in no significant change to hot metal chemistry.

\subsubsection{Burden Permeability}

The crushed and drained oil filter appears to have dimensions approximating 3 in to 4 in diameter by about 1 in high as observed in Peaslee.$^{26}$ An observation of Figure 3 in the previously referenced work would indicate that a crushed and drained filter should be reasonably free flowing in bulk, and of a large enough particle size so as not to provide restrictions to gas flow in the burden or subsequent decrease in burden permeability. This comment is the opinion of the authors and will need verification by blast furnace operators and/or trials.

\subsubsection{Process Flow Diagram}

In order to help clarify and identify to the reader the overall effect of the charging of UOF's to the iron blast furnace, two process flow diagrams have been constructed. The first, Figure 5 shows the blast furnace material balance for a conventional practice. 


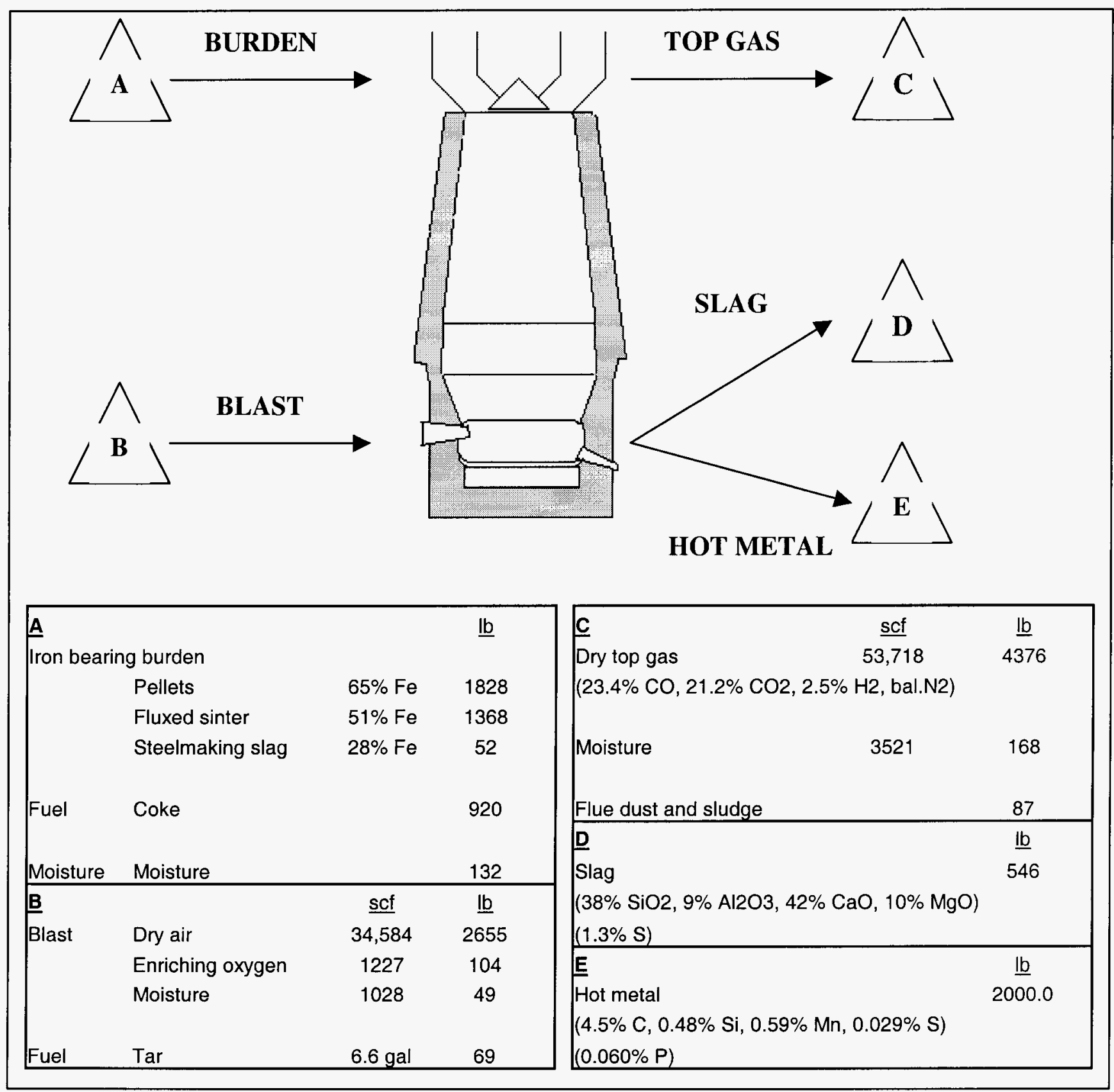

Figure 5: Blast furnace material balance for a conventional practice ${ }^{62}$

A revised material balance for the blast furnace has been calculated from the information shown in Figure 5, for the addition of a $2 \%$ charge of UOF's added to the burden. A comparison of the material balance shows a very small effect on the overall material balance from the addition of this $2 \%$ UOF charge.

${ }^{62}$ From: D. H. Wakelin, Blast Furnace Material and Energy Balance. The Making, Shaping and Treating of Steel, $11^{\text {th }}$ Edition, Ironmaking Volume, p734, sec 10.3.5, 1999. 


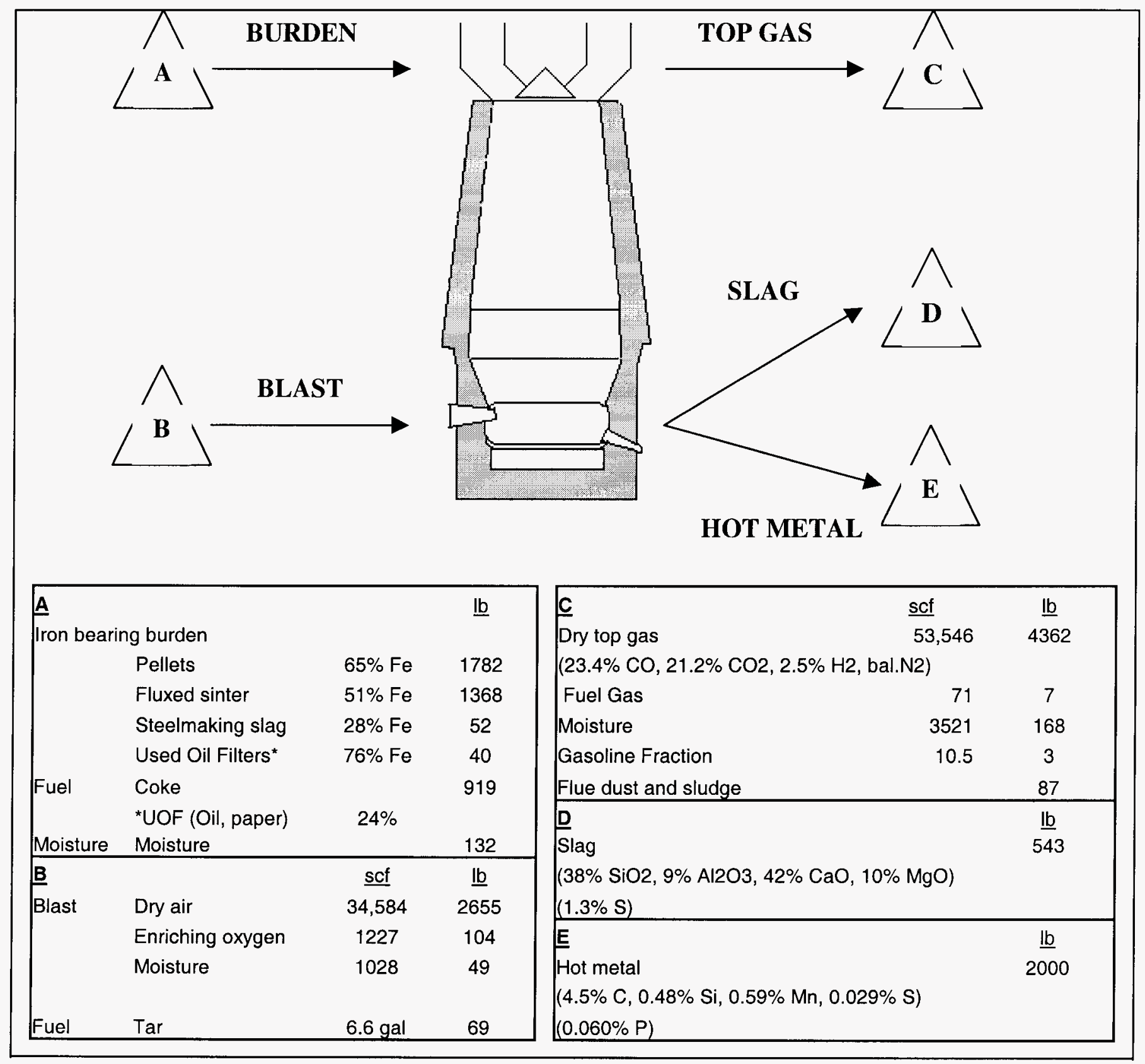

Figure 6: Blast furnace material balance for a $2 \%$ recycle rate of used oil filters in the burden ${ }^{63}$

\subsubsection{Effect on Gas Cleaning}

Recycling of UOF's is not expected to result in any significant complication in the cleaning of the particulates in the blast furnace top gas. The received materials would be as crushed and/or densified oil filters with or without internal components. As such, these solids would not disintegrate until well below the upper surface of the burden. The

${ }^{63}$ As calculated by the writer. 
filtered media contained within an oil filter could be an off gas problem if the filter were not compacted within the steel container.

Any filter material entering the burden within the UOF, would be trapped until much deeper into the burden where the temperatures would be sufficient for full pyrolysis of the cellulose material of the filter. Both the pyrolysis of motor oil and of the filter media would occur simultaneously. Therefore, additional particulate contamination of the top gas stream does not appear to be a problem.

As pointed out in section 4.3.3.1, The chemistry of Motor Oil in the Blast Furnace, $98.2 \%$ of the amount of oil charged into the furnace with the UOF will leave in the top gas in the vapor phase. The lighter hydrocarbons will remain as fuel gas equal to about $67.9 \%$ of the original charged oil weight. The other $30.3 \%$ of the somewhat higher hydrocarbon fraction, referred to as "gasoline", will condense in the water scrubbing system.

Once the gasoline fraction is condensed, $14 \%$ of this fraction will be benzene and $14 \%$ toluene with the balance in the $\mathrm{C} 5$ to $\mathrm{C} 10$ range. Detailed examination of the water treatment plant will be required to determine if additional actions need to be taken to remove these constituents prior to discharge.

\subsubsection{Effect on Blast Furnace Gas Heating Value}

About $67.9 \%$ of the oil entering the top of the furnace will undergo pyrolysis and be converted into lighter hydrocarbons, approximating an average heating value of methane, $\mathrm{CH}_{4}$. As such, this fuel gas would have a heating value of approximately $1,000 \mathrm{Btu} / \mathrm{ft}^{3}$.

Although this fuel gas, equivalent to methane, appears to be a potentially large increase in heating value, it must be remembered that the total oil charged to the furnace is a relatively small percentage, approximating only about 13 weight percent for each fraction of the blast furnace burden occupied by UOF's, i.e. approximately $13 \%$ oil from the $2 \%$ UOF's charged to the blast furnace the equivalent of $0.26 \%$ methane entering the top gas stream. 


\subsection{Capital Cost Considerations}

The capital cost associated with charging UOF's into the blast furnace cannot be quantitatively expressed until a determination is made as to the weight fraction of burden that UOF's will occupy. As previously mentioned, the authors of this study have subjectively indicated an approximate $2 \%$ of the burden as being a potential target figure for charging UOF's into the blast furnace. The following capital cost considerations will be based upon this approximation, but once more definitive charging percentages can be determined, more accurate cost effects could be developed.

\subsection{Storage}

The majority of blast furnace burden materials are delivered to the stockhouse by railroad. These materials are delivered in iron ore cars where by they may be emptied by means of a rotary car dumper, or in bottom dump hopper cars for discharging directly into receiving bins. Transfer cars are used to deliver additional materials to the stockhouse.

The receipt of UOF's into a storage location will need to accommodate some amount of oil leakage from the material. Considerations for protected storage to avoid contamination with rainwater by the used motor oil may be appropriate. The potential amount of oil that may drain from previously drained and crushed UOF's is not presently known and will need to be evaluated to determine the criteria for an engineering solution for the storage requirements.

The most important criteria in this regard is to keep any free draining oil from entering sumps and drains associated with the storage facility. Communication and cooperation between the suppliers and the buyers can be a major factor to reduce and/or control any free draining oil.

\subsection{Handling and Charging}

As long as the overall size of UOF's are below 6 in $\times 6$ in and preferably less than below 4 in $\times 6$ in, and preferably in the range of 3 in $\times 4$ in, the normal bulk material handling system should be relatively unaffected. UOF's in the drained and crushed form would be reasonably free flowing in normal blast furnace materials handling systems.

\subsection{Processing of Oil Filters}

One case study for an originator of UOF's is the New York City Department of Sanitation Bureau of Motor Equipment. ${ }^{64}$ On an annual basis the New York Department of Sanitation diverted 50 tons of filters from disposal to recycling. The overall cost per ton of export (UOF's) was $\$ 100 /$ ton. The recycling program avoided a solid disposal cost of approximately $\$ 5,000.00$, but the recycling company charged $\$ 48,024.00$ for a net program increase of $\$ 43,024.00$. However it is stated that there is a reduced cost and liability associated with hazardous waste disposal and minimizing the volume of waste disposed.

${ }^{64}$ Recycling Oil and Fuel Filters, www.nycwasteless.com/citysense/initiaves/dosfilters.htm, 2000. 
The above example shows that the immediate cost of recycling oil filters is significantly higher than landfill. Due to environmental considerations, landfill of UOF's may not be feasible in the future.

However, the approximately $\$ 100 /$ ton of UOF's charged by the recycler may contain sufficient incentive to develop a direct recycling program with a consumer of the end product i.e. a steel mill. The fees charged by the recycling company could be a significant means for properly preparing the UOF's for size and residual oil to meet the requirements of recycling in the blast furnace.

\subsection{Top Gas Cleaning}

Charging of UOF's would not result in any capital costs associated with the dry particulate cleaning of the top gas.

\subsection{Waste Water Cleaning}

This study has indicated that approximately $30 \%$ of the residual oil contained in the UOF's will be pyrolyzed into a condensate that would be condensed by the scrubber wash water at an operating temperature of $80^{\circ} \mathrm{F}$. An analysis of this aspect was not included in the scope of work for this study and may be developed in a later study, if deemed appropriate. 


\subsection{Operating Cost Considerations}

Because UOF's are not a regular part of the blast furnace burden, there is no published market price for this material. US Steel has indicated that UOF's are currently delivered FOB their Gary Works at $\$ 30$ per gross ton. A metallic yield of $80 \%$ would result in low residual iron units at about $\$ 35.60$ per net ton Fe. The following cost considerations will be of a qualitative approach to indicate where additional costs and/or benefits may be obtained and or examined in more detail in the future.

\subsection{Hot Metal Production}

Charging metallics to a blast furnace will significantly increase productivity. If metallics are added, the only energy required is melting energy. Whereas, when iron oxides are charged, the energy of chemical reduction is required to separate the iron oxide into the metallic iron as well as the heat energy to bring the reaction products to tapping temperature. Many blast furnace operators significantly increase the metallic charge to one operating blast furnace when another blast furnace in the same plant must be taken off line for repair or relining. This is also done on an intermittent basis to balance out production requirements from a single blast furnace before starting a second blast furnace.

A technical paper prepared by $A K$ Stee ${ }^{65}$ in 1994 is a useful reference as to blast furnace productivity benefits derived from several process improvements. Although this technical paper included a metallic charge involving hot briquetted iron, the productivity relationship may be extrapolated to a consideration of UOF's.

The AK Steel experience showed a relationship of an increase in the production of the blast furnace in NTHM/day being increased by the amount of tons/day of HBI Charged. This particular $\mathrm{HBI}$ material demonstrated an increased production rate $\mathrm{Y}$, of $Y=0.928 X+4846.6$ : with 4846.6 being the initial production rate in tons per day prior to charging $\mathrm{HBI}$, and $X$ being the amount of $\mathrm{HBI}$ charged in tons per day. The coefficient 0.928 is approximately equal to the total Fe content of the $\mathrm{HBI}$ charged, of which $92 \%$ is expected to be in the metallic form, as shown in Figure 7 of the AK Steel reference.

From the above relationship, we may assume that an increase in blast furnace productivity may be approximated by utilization of the metallic Fe content of the charged material on the same basis as AK's experience with the HBI. The use of this relationship in a calculation for crushed and drained UOF's having a demonstrated yield of $76 \%$ would result in a production increase for an average blast furnace producing 4,920 NTHM/day of approximately $1.4 \%$ with a charging rate of UOF's of $2 \%$ of the burden. ${ }^{66}$

\footnotetext{
${ }^{65}$ D.A. Kercsmar, et al., Sustained Production in Excess of 9 Tons Per Day/lo0 ft ${ }^{3}$ WV at Middletown's No. 3 Blast Furnace, Iron \& Steelmaker, p 33, July 1994.

${ }^{66}$ K.D. Peaslee \& D.E. Roberts, II, " The Future of Used Oil Filter Recycling in Missouri: An Evaluation of Potential Processes, Product, Quality, Recycling Locations, \& Economics", Missouri Department of Natural Resources, p 19, February 15, 1997.
} 
However, this production rate increase of $1.4 \%$ in NTHM/d for a $2 \%$ charge of UOF's may be increased or decreased depending upon the energy required for the pyrolysis of the contained oil within the UOF.

\subsection{Slag Production}

Expectations are that there would be no increase or decrease in operating costs related to slag production.

\subsection{Top Gas Production}

The used motor oil contained in the UOF's will undergo a distillation such that for each $100 \%$ of oil entering the furnace, $67.9 \%$ would exit the top gas as fuel gas and $30.3 \%$ would exit as a gasoline fraction in the vapor phase. In the demonstration case of a $2 \%$ UOF charge to the burden, or $40 \mathrm{lb}$ UOF's/NTHM, for the case of drained and crushed filters this would represent a $13 \%$ weight of oil or $5.2 \mathrm{lb} /$ ton of motor oil that would be released into the top gas as $3.5 \mathrm{lb} /$ ton fuel gas and $1.6 \mathrm{lb}$ of gasoline in the vapor phase. The $3.5 \mathrm{lb} / \mathrm{NTHM}$ of $\mathrm{CH}_{4}$ would be equivalent to approximately $378 \mathrm{scf}$. At a natural gas energy value of $\$ 2.50 / 1,000 \mathrm{scf}$, this would represent a value increase in the fuel gas of $\$ 0.94 / N T H M$ credit. scrubber.

The $\mathrm{C}_{5}$ and higher hydrocarbons in the gasoline fraction will be condensed in the

\subsection{Fuel Requirements}

Estimations indicate that a $2 \%$ charge of UOF's (40 lb UOF/NTHM) would contribute about $0.72 \mathrm{lb}$ coke/NTHM. If one is to assume an average coke price delivered to the skip of the blast furnace at $\$ 120 / \mathrm{t}$ coke, a credit of $\$ 0.043 / \mathrm{NTHM}$ may be estimated as a benefit.

\subsection{Flux Requirements}

There is no anticipated increase or decrease in costs associated with flux and/or slag.

\subsection{Iron Yield}

Iron yield is estimated to be recovered at the rate of $100 \%$ of the contained $\mathrm{Fe}$ in the UOF's charged to the blast furnace. At the example rate of $2 \%$ of the burden charged as UOF's (40 lb UOF/NTHM) the yield, as previously described, is estimated to be $76 \%$. Therefore the $40 \mathrm{lb}$ UOF/NTHM would yield $30.4 \mathrm{lb}$ Fe/NTHM. Because the pricing structure for UOF's delivered to the blast furnace is not currently known, it is not possible to calculate an estimated benefit for the additional $30.4 \mathrm{lb}$ Fe/NTHM resulting from UOF's charged to the blast furnace.

\subsection{Gas Cleaning}

There is no change to operating costs for the dry portion of the top gas cleaning operation. 


\subsection{Waste Water Treatment}

Some additional process water/waste water treatment costs will increase due to the vapor fraction in the hydrocarbon range referred to as "gasoline", $C_{5}$ to $C_{10}$ will condense in the gas cleaning system within the scrubber. This will result in hydrocarbons within the gasoline fraction to be removed from the process water and the wastewater stream for prior to discharge.

The quantity of this gasoline fraction is estimated to be $1.6 \mathrm{lb} / \mathrm{NTHM}$ for a $40 \mathrm{lb}$ UOF/NTHM charge. This would contain $0.23 \mathrm{lb}$ of benzene and $0.23 \mathrm{lb}$ of toluene per NTHM.

The cost of wastewater treatment has not been included within the scope of work for this study. Therefore, it is not known at this time whether or not the condensate would be removed within the normal process water/wastewater treatment plant for a modern blast furnace, or not. 


\subsection{Analysis}

In section 4.3 Recycling of Used Oil Filters to the Blast Furnace, calculations were made to show the recycling capability of 19 blast furnaces in the U.S. consuming all available filters as well as one western blast furnace consuming all filters west of the Mississippi as an extreme hypothetical case. Under conditions that assume a future growth of oil filter recycling and increased production of oil filters, and a $70 \%$ recycling rate in the year 2005 results in an average charge of only $0.3 \%$ of steel components from the UOF's recycled to the average blast furnace. This would obviously be too small an amount for an operator to deal with, and so the calculations showed an increase concentration going to one furnace as an example at a steel-charging rate of $1.3 \%$ to the burden.

Another way to look at the potential for balancing UOF generation rate against BF capacity on a regional basis may be demonstrated by the following example. In this case, two regional markets Chicago and Pittsburgh have been selected.

In the case of the Chicago market, and assuming $100 \%$ UOF recycling from the adjoining states of lowa, Illinois, Indiana, Michigan, and Wisconsin, a total of 31.2 million UOF's at an average weight of $0.79 \mathrm{lb}$ would result in 12,300 tons of UOF's (including the oil) for recycle to one Chicago blast furnace. This would be an equivalent charging rate of $0.82 \%$ UOF's to one blast furnace at a rate of $1.5 \mathrm{Mtpy}$.

If a regional market centered on Pittsburgh were considered, then UOF's obtained from the states of New York, Connecticut, New Jersey, Pennsylvania, Maryland, Delaware, and Ohio, would be 43.5 million UOF's at a $100 \%$ recycling rate. This number of filters times $0.79 \mathrm{lb} /$ UOF equals 17,100 tons UOF per year. This would represent a charging rate of $1.1 \%$ UOF's/NTHM.

The overall usage rate within this study encompassed an average of $2 \%$ crushed and drained UOF's, per NTHM. The writer's opinion is that this may represent a reasonable average charging rate upon which to base the calculations for this study. Actual operations may significantly change this average charging rate to a smaller fraction or a much greater fraction depending upon the operating philosophy. However, operating at a rate greater than $2 \%$ UOF's/NTHM would necessarily mean an intermittent operation as the availability of UOF's would be limited.

\subsection{Operational Considerations}

The writers have assumed that the used oil filters, having been first properly hot drained and then subsequently crushed, would represent a reasonable, least cost supply of UOF's to the blast furnace. Any filter media remains within the crushed and drained UOF, will act as a sponge to inhibit further draining of oil. Additional examination of crushed and drained UOF's in bulk will be required to evaluate whether or not such UOF processing will relieve the problems of oil contamination from material handling and storage considerations at the blast furnace storage and stockhouse. 
Charging of crushed and drained UOF's to the blast furnace at a bulk density of $50 \mathrm{lb} / \mathrm{ft}^{3}$ is a metallic charging practice that may be similar to other scrap charges used in the blast furnace. In section 4.3.3.1 The Chemistry of Motor Oil in the Blast Furnace, a detailed approach to the behavior of motor oil in entering the upper zone of the blast furnace with the charged materials has been shown. Motor oil has a high boiling point, such that it would remain liquid at $400^{\circ} \mathrm{F}$, thereby entering the burden within the drained and crushed UOF. During the next one to two hours as temperatures increase from $750^{\circ} \mathrm{F}$ to $1100^{\circ} \mathrm{F}$, the motor oil would pyrolyze into lighter hydrocarbons which would leave the burden with the top gas and heavier hydrocarbons which would undergo further pyrolysis until becoming coke. The resulting coke from the pyrolysis of the motor oil would represent about $2 \%$ of the weight of motor charged into the furnace. Although some concerns have been expressed about the possibility of polycyclic aromatic hydrocarbons (PAH's) because of the possibility of connection to known carcinogens, this risk appears to be exceedingly small as these heavier PAH's would be pyrolyzed in the higher temperature zones of the furnace.

The lighter weight fractions of the motor oil input to the furnace would be discharged from the blast furnace as fuel gas, $67.9 \%$ of the weight of motor oil charged, and a "gasoline" fraction representing $30.3 \%$ of the weight of motor oil charged which would condense in the wet scrubber of the off gas system. The absolute quantities of "gasoline" condensate at a charging rate of $2 \%$ UOF's/NTHM would be1.6 Ib/NTHM.

The effect of this $1.6 \mathrm{lb}$ "gasoline" fraction lb/NTHM may have on the process water and wastewater treatment is outside of the scope of this study. If subsequent study of this water treatment issue would indicate it to represent a significant cost item, then the processing of UOF's to the blast furnace would require shredding of the filters by the processor and briquetting of the shredded material into "bricks" or "pucks". There are some UOF processors within the United States that do shredding of the UOF's. This has been commented in section 3.5 Processing.

In the event that a UOF shredding operation would be required, the resulting metallic units recovered form this process would have no adverse affect on blast furnace operations and, could be handled as any other metallic charged to the blast furnace.

\subsection{Cost/Benefit Review}

At this stage of the feasibility study, it is not possible to accurately quantify additional costs and/or benefits to derived in a \$/NTHM of hot metal produced. The best approach at this stage is to identify, in a qualitative manner, the areas that will be expected to see either an increase cost or a benefit to be derived from the charging of UOF's to the blast furnace.

Table 19, Relative Cost vs. Benefit of Charging Used Oil Filters to the Blast Furnace, has been constructed to show these relationships, in the writer's opinion, which may result from the charging of UOF's to the blast furnace. 
Table 19: Relative Cost vs. Benefit of Charging Used Oil Filters to the Blast Furnace

\begin{tabular}{|l|c|c|}
\hline \multicolumn{1}{|c|}{ Item } & Higher Cost & Benefit \\
\hline Storage & + & + \\
\hline Iron Ore & & + \\
\hline Metallics & 0 & 0 \\
\hline Fluxes & & + \\
\hline Coke & & + \\
\hline Production & 0 & 0 \\
\hline Hot Metal Analysis & 0 & 0 \\
\hline Slag Production & 0 & 0 \\
\hline Slag Analysis & 0 & 0 \\
\hline Gas Cleaning & + & \\
\hline Water Treatment & & + \\
\hline Fuel Value & $?$ & $?$ \\
\hline Maintenance & & \\
\hline
\end{tabular}

With the present knowledge base, it may be expected that additional cost may be incurred relative to UOF storage and in water treatment resulting from the condensation of "gasoline fraction" hydrocarbon phases in the gas cleaning scrubber water for treatment. An unknown factor is whether or not the additional hydrocarbon vapors may result in additional maintenance problems, and/or possible oil leakage from the UOF's that may require additional maintenance considerations.

On the benefit side, there exists a reduction in iron ore pellet requirements, the potential for reduced metallics costs, an increase in the production rate and less coke due to charging metallics, a higher fuel value in the blast furnace top gas, and an unknown cost/benefit relationship relative to maintenance.

At this stage of the feasibility study, it appears that there is potential incentive to determine what is required to conduct additional industrial trials for the recycling of UOF's to the blast furnace. To assist in this aspect, the section 8.0 Review with Blast Furnace Operators, which follows, will serve to highlight the past experiences that have been brought to the attention of this feasibility study by operators solicited by AISI and the writer. 


\subsection{Review with Blast Furnace Operators}

William Obenchain of the AISI provided the writer with blast furnace operator contacts at Bethlehem Steel, Dofasco, Ispat Inland, USS and WCI Steel.

\subsection{Past Experiences with Oily Charge Materials}

During the review of this feasibility study with blast furnace personnel at US Steel, it was learned that USS reported continuing experience in charging UOF's into their iron blast furnace at the Gary Works. This work has been underway for at least five or six years. The current cost of the UOF's is about $\$ 30$ per gross ton delivered to the Gary Works.

USS has been receiving approximately 100 tons to 200 tons of UOF's per month. These are delivered by dump truck at about 20 tons per load. The UOF's are dumped onto the scrap blending concrete pad. A front-end loader is used to distribute the UOF's throughout the scrap (B scrap, and other steel plant metallics) for blending.

The blended metallic charges are then loaded by front-end loader into a transfer car to be discharged into the metallic/scrap bin at the stock house. The skip car is loaded by a material gathering conveyor, which receives all burden materials from the stockhouse for delivery into the skip car.

The UOF's are blended with scrap at a rate of 100 tons to 200 tons UOF's per 30,000 tons to 40,000 tons of scrap per month or about $0.3 \%$ to $0.5 \%$ UOF in the scrap blend. At a concentration of $0.5 \%$ UOF in the scrap blend, and assuming a $400 \mathrm{lb}$ scrap per NTHM charging rate, this would represent a UOF charging rate of $0.1 \%$ in the overall burden.

The discussion USS personnel indicated that no problems had been experienced with respect to oil draining from the UOF's and that because the scrap is blended on a concrete pad, any potential drainage would be contained. Additionally, there were no known operational problems with respect to the blast furnace operations or its top gas treatment and water treatment. The charging rate at $0.1 \%$ in the overall burden is a very small amount and may be insufficient to disclose potential problems if larger amounts may be charged.

\subsection{Perceived Problems with Charging Oil Filters}

The other blast furnace operators representing Bethlehem Steel, Dofasco, Ispat Inland and $\mathrm{WCI}$ Steel all expressed concerns relating to the contained oil. The initial concerns are that any free flowing oil from the filters may be a material storage and handling problem resulting in contamination of the ground and/or ground water.

Communications between buyers and suppliers of UOF's in the supply chain should be able to properly address any concerns over freely draining oil. 
The next major concern expressed by all of these operators was the extent to which oil would vaporize in the top of the furnace. The concern is that the vaporized oil would condense and contaminate the scrubber wash water system.

Other concerns expressed were the potential difficulties based on the final size of the oil filter in charging with a Paul Worth top and also with potential problems in conveyor charging systems due to concerns on poor material flowability.

One operator indicated that they have optimized the blast furnace process to a controlled temperature of the top gas. They did not think it would be worthwhile to reoptimize furnace practices for a small percentage of a material that could potentially cause problems.

Most operators felt that the UOF's would need to be priced at a low level relative to other metallics, or they would not be interested in interrupting normal material balances to the process. 


\subsection{Future Work}

The only remaining concern of blast furnace operators not answered in the feasibility study is with respect to the effect of the vaporized oil components on the operating cost and capital cost of the top gas cleaning system to comply with all regulations.

At the time this study was authorized, it was not known that US Steel at Gary Works had a continuing program of charging UOF's into their blast furnaces.

Due to the fact that US Steel does have operating experience with recycling UOF's into the blast furnace, consideration may be given to conducting a study of the operational results at that blast furnace site. This has the benefit of not incurring any significant cost to conduct a demonstration for the feasibility of this concept. However, it must be consistent with US Steel's policies and procedures regarding any proprietary or confidential operating practices and procedures.

If an analysis of the USS Gary experience can be shared with other blast furnace operators, then the potential for significant additional recycling of UOF's to the blast furnace may readily occur.

The other significant aspect to be developed is the requirement for proper preparation of UOF's for shipment, delivery and storage to the BF operators. This analysis would need to obtain information from originating scrap yards as well as material receiving and handling operations at the steel works.

It will be necessary to collect additional information with respect to motor oil that may drain from crushed and drained UOF's during transportation and storage prior to charging into the blast furnace. In the event that free draining of motor oil from the UOF's is found to be in excess of steel plant requirements, then consideration needs to be given toward the shredding and separation of oil and filter media from the steel components, and the compaction and/or briquetting of the shredded steel components for blast furnace charging. 


\subsection{Conclusions}

This feasibility study has identified the major parameters to be considered in recycling of used automotive oil filters to the iron blast furnace. Properly hot drained oil filters do not represent a federal environmental hazardous waste, although several states have legislation prohibiting the landfilling of used oil filters. The present weight of steel contained in used oil filters (UOF's) for recycling is about $122,000 \mathrm{t} / \mathrm{yr}$.

The least cost delivery of UOF's to the blast furnace would be properly hot draining followed by crushing of the filter. This is expected to result in approximately $13 \%$ oil remaining in the filter media within the crushed filter. The chemistry of the used oil, when charged in to the top of the blast furnace, indicates that about $98 \%$ of the weight of this oil would be removed from the furnace in the blast furnace top gas as both fuel gas and as a condensable "gasoline fraction" that would condense in the scrubber water. The fuel gas is a positive benefit, but it is not known to what extent the condensable "gasoline fraction" would represent additional water treatment costs.

In the event that a $13 \%$ contained oil in crushed and drained UOF's is excessive, then a UOF processing route that encompasses shredding of the filter, separation of filter media, collection of used motor oil for its recycling, and compaction of the shredded metal may be required to provide a charge material to the blast furnace. This subsequently shredded and compacted charged material should, in the writer's opinion, have no detrimental effect to the recycling of this material through the blast furnace with respect to top gas chemistry or any contamination of the hot metal chemistry, but it would incur additional cost.

The charging of metallic iron units to the top of the blast furnace is a routine practice in the industry. To be acceptable to the blast furnace operator, recycling of steel from used oil filters must be conducted in a way that will not cause environmental remediation costs and/or operational problems, which outweigh the potential cost benefits of recycling this material.

Due to the fact that used oil filters are presently being recycled in the blast furnaces at US Steel, Gary Works, a study of this practice would benefit the industry. Such a study would need to be consistent with the policies and confidentiality requirements of US Steel. The current cost of the UOF's is about $\$ 30$ per gross ton delivered to the Gary Works.

The analysis conducted in this study has been mainly oriented to the use of a $2 \%$ charge of UOF's to the blast furnace burden. The US Steel practice at $0.1 \%$ UOF's may be too low to indicate any potential problems. However, on a geographically distributed basis, there may not be nearly enough total volume of UOF's generated to charge more than about 0.5 weight percent of the burden to a blast furnace. In this case, provided transportation costs are not excessive, sufficient blast furnace capacity exists to recycle all UOF's that may be reasonably delivered to the steel plant.

Currently electric furnace steel plants as well as iron foundries consume significant amounts of the existing recycled UOF's. 
Future work should be directed to establishing the criteria for processing of UOF's to be acceptable to the blast furnace from a size, density and residual oil content basis. Additionally, a more detailed assessment of wastewater treatment costs may be required to properly accommodate the condensable fraction of the vaporized oil species.

There is strong indication that additional states may enact legislation banning the disposal of UOF's into landfills. This will result in increased cost to the public for disposal of these necessary maintenance activities on their automobile, unless beneficial recycling can be organized. Through a combination of developing the requirements of UOF's for blast furnace recycling, publicity to the originating sources of UOF's, and development of an appropriate and responsible transportation link; the recycling of UOF's into the blast furnace may be mutually beneficial to the environment and to the steel industry.

\subsection{Acknowledgements}

The writers would like to acknowledge participation and advice from the following companies and their personnel.

$\begin{array}{ll}\text { Bethlehem Steel } & \text { Fred Rorick } \\ \text { Dofasco } & \text { Randy Fischer } \\ \text { Ispat Inland } & \text { Wendell Carter } \\ \text { US Steel } & \text { Ed O'Donnell } \\ & \text { Jon Burgo } \\ & \text { Ted Weitzel } \\ \text { WCI Steel } & \text { Bill Sherwood } \\ \text { Wheeling-Pittsburgh Steel } & \text { Ed Asbury } \\ \text { Kvaerner, Pittsburgh } & \text { Neil Goodman }\end{array}$




\subsection{Appendix}

Appendix 1: State Motor Vehicle Registrations $1999^{67}$

\begin{tabular}{|c|c|}
\hline STATE & $\begin{array}{c}\text { All } \\
\text { Vehicles }\end{array}$ \\
\hline Alabama & $4,006,454$ \\
\hline Alaska & 586,393 \\
\hline Arizona & $3,751,417$ \\
\hline Arkansas & $1,839,611$ \\
\hline California & $26,782,040$ \\
\hline Colorado & $3,953,175$ \\
\hline Connecticut & $2,819,692$ \\
\hline Delaware & 626,315 \\
\hline Dist. of Col. & 236,987 \\
\hline Florida & $11,625,429$ \\
\hline Georgia & $7,059,719$ \\
\hline Hawaii & 737,409 \\
\hline Idaho & $1,170,422$ \\
\hline Illinois & $9,571,901$ \\
\hline Indiana & $5,604,559$ \\
\hline lowa & $3,175,168$ \\
\hline Kansas & $2,274,030$ \\
\hline Kentucky & $2,703,894$ \\
\hline Louisiana & $3,547,570$ \\
\hline Maine & 946,408 \\
\hline Maryland & $3,942,270$ \\
\hline Massachusetts & $5,436,298$ \\
\hline Michigan & $8,457,526$ \\
\hline Minnesota & $4,136,503$ \\
\hline Mississippi & $2,348,984$ \\
\hline Missouri & $4,461,573$ \\
\hline Montana & $1,020,121$ \\
\hline
\end{tabular}

\begin{tabular}{|c|c|}
\hline STATE & $\begin{array}{c}\text { All } \\
\text { Vehicles }\end{array}$ \\
\hline Nebraska & $1,589,184$ \\
\hline Nevada & $1,185,875$ \\
\hline New Hampshire & $1,098,554$ \\
\hline New Jersey & $6,208,305$ \\
\hline New Mexico & $1,607,151$ \\
\hline New York & $10,899,573$ \\
\hline North Carolina & $5,769,173$ \\
\hline North Dakota & 720,799 \\
\hline Ohio & $10,476,193$ \\
\hline Oklahoma & $2,984,763$ \\
\hline Oregon & $3,079,568$ \\
\hline Pennsylvania & $9,209,429$ \\
\hline Rhode Island & 766,220 \\
\hline South Carolina & $3,073,091$ \\
\hline South Dakota & 807,722 \\
\hline Tennessee & $4,489,504$ \\
\hline Texas & $14,237,616$ \\
\hline Utah & $1,601,854$ \\
\hline Vermont & 535,278 \\
\hline Virginia & $5,928,621$ \\
\hline Washington & $4,969,440$ \\
\hline West Virginia & $1,398,578$ \\
\hline Wisconsin & $4,458,578$ \\
\hline Wyoming & 544,119 \\
\hline Total & $220,461,056$ \\
\hline Puerto Rico & $2,103,526$ \\
\hline
\end{tabular}

67 "State Motor Vehicle Registration 1999 Table MV-1," http://wwwcf.fhwa.dot.gov/ohim/hs99/tables/mvl.pdf, 10/25/2001

Metserv 
Appendix 2: Estimate of Oil Filter Can Zinc Coating Weight

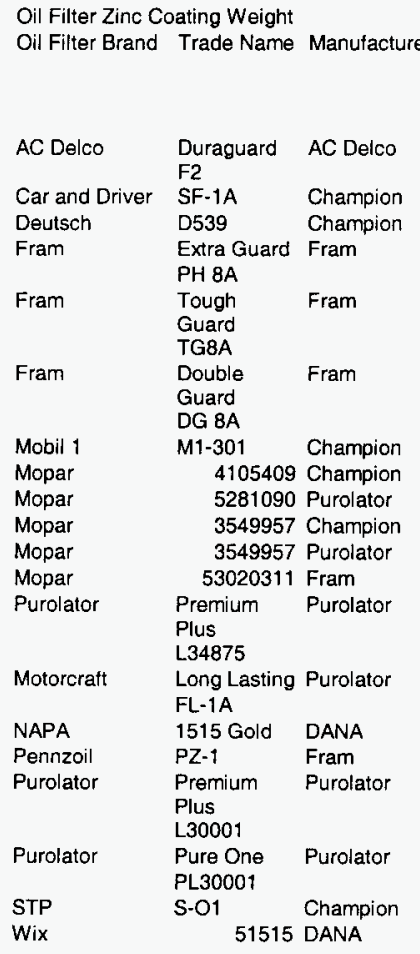

Zinc Coating Weight Filter Can Area

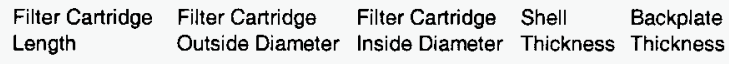

(in)

$$
4.626
$$

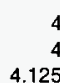

4.125

4.125

4.125

4.25
2.375

2.375
2.675

2.675
3

3.125

4.25

4.1

4.125

4
4.125

4
4.125

4.125

4.125

4
4

\subsection{5}

3.25
3.25
3$$
3
$$$$
3
$$$$
3
$$

\subsection{5}

3.25
2.675

2.675
3.25

3.25
3.25

3.25
3.25
3.2

3.2

3.2

3.25

3.25

3.25
3

3
3.25

3.25

3.25 (in)

\begin{tabular}{ccc} 
& \multicolumn{1}{l}{ (in) } & \multicolumn{1}{l}{ (in) } \\
1.375 & 0.015 & 0.1 \\
& & \\
1.625 & 0.012 & 0.102 \\
1.625 & 0.012 & 0.102 \\
1.375 & 0.015 & 0.089 \\
& & \\
1.625 & 0.015 & 0.187 \\
& & \\
& & \\
1.625 & 0.015 & 0.187 \\
& & \\
1.625 & 0.022 & 0.138 \\
1.675 & 0.01 & 0.115 \\
1.625 & 0.01 & 0.115 \\
1.625 & 0.012 & 0.102 \\
1.625 & 0.01 & 0.115 \\
1.625 & 0.014 & 0.11 \\
1.625 & 0.015 & 0.14 \\
& & \\
1.625 & 0.011 & 0.12 \\
& & \\
1.625 & 0.014 & 0.104 \\
1.375 & 0.015 & 0.089 \\
1.625 & 0.011 & 0.115 \\
& & \\
1.625 & 0.011 & 0.115 \\
1.625 & 0.012 & 0.102 \\
1.625 & 0.014 & 0.104 \\
& &
\end{tabular}

Filter Can Zinc Coating

Surface Area Weight

(tt^2) elongation

0.937

0.780

0.780

0.742

0.742

0.742

0.829

0.381

0.381
0.522

0.585

0.609

0.816

0.787

0.804

0.780

0.742

0.804

0.804

0.780

0.780

Average Wt.
0.00371

0.00468

0.00390

0.00390

0.00371

0.00371

0.00414

0.00191

0.00261

0.00292

0.00305

0.00408

0.00394

0.00402

0.00390

0.00371

0.00402

0.00402

0.00390 0.00390

0.00369

$0.10 \mathrm{oz} / \mathrm{sq}$. ft.

Cartridge Outside Diameter Area $\times \mathrm{PI}+10 \% \times$ Cartridge Height $+20 \%$

Appendix 3: Rules Summary for Used Oil Filter Disposal

\begin{tabular}{|l|l|}
\hline State & Oil Filter Disposal Rules \\
\hline Alabama & $\begin{array}{l}\text { Federal Guidelines: Non-terne plated used oil filters are exempt } \\
\text { from hazardous waste regulations if the used oil filter is: }\end{array}$ \\
& $\begin{array}{l}\text { a) punctured through its dome end or its anti-drain back valve and } \\
\text { hot-drained; or }\end{array}$ \\
& $\begin{array}{l}\text { b) hot-drained and crushed; or } \\
\text { c) dismantled and hot-drained; or } \\
\text { d) hot-drained using an equivalent method to remove used oil. } \\
\text { Definitions: Terne is an alloy of lead and tin that was used in } \\
\text { some heavy duty filters in the past. Hot draining is defined as } \\
\text { draining the oil filter at near engine operating temperature and } \\
\text { above 60 degrees Fahrenheit for a recommended 12 hours. }\end{array}$ \\
& $\begin{array}{l}\text { If these conditions are not met, the filters must be tested or } \\
\text { assumed to be hazardous waste and managed accordingly. }\end{array}$ \\
\hline Alaska & Federal Guidelines: See Alabama \\
\hline Arizona & Federal Guidelines: See Alabama \\
\hline
\end{tabular}




\begin{tabular}{|c|c|}
\hline Arkansas & Federal Guidelines: See Alabama \\
\hline California & $\begin{array}{l}\text { In California used oil filters are considered non-hazardous if: } \\
\text { 1. They are drained of free flowing oil, which includes removal } \\
\text { of any barrier to free-flowing oil, crushing, opening, } \\
\text { puncturing, or in any other manner that removes oil. } \\
\text { 2. They are processed for metal reclamation (recycling). } \\
\text { 3. They are stored and transferred in a closed, rainproof } \\
\text { container that is designed to keep spilled oil inside the } \\
\text { container. Drums of filters need to be labeled "drained used } \\
\text { oil filters" and must indicate the initial date of accumulation on } \\
\text { each container. } \\
\text { Storage Limits: } \\
\text { 1. Less than } 1 \text { ton }-1 \text { year } \\
\text { 2. } 1 \text { ton or more-180 days } \\
\text { Call CA Dept of Toxic Substances for other rules. }\end{array}$ \\
\hline Colorado & Federal Guidelines: See Alabama \\
\hline Connecticut & $\begin{array}{l}\text { 1. Oil must be removed from the filter by puncturing and gravity } \\
\text { draining for at least } 24 \text { hours or by crushing the filter. A } \\
\text { combination of crushing and draining is preferred. } \\
\text { 2. The drained oil must be collected and recycled } \\
\text { 3. The oil filter can be disposed of in a permitted solid waste } \\
\text { landfill. } \\
\text { Generators and collectors of used oil filters must obtain a permit. }\end{array}$ \\
\hline Delaware & Federal Guidelines: See Alabama \\
\hline D.C. & Federal Guidelines: See Alabama \\
\hline $\begin{array}{l}\text { Florida } \\
\text { Florida, Continued }\end{array}$ & $\begin{array}{l}\text { Used oil filters generated by commercial entities may not be land } \\
\text { filled in Florida. A commercial generator of used oil filters must } \\
\text { have the filters managed by a registered processor or must register } \\
\text { with the Dept. of Environmental as a used oil filter processor. } \\
\text { Contact FL Dept. of Env. Protection, Hazardous Waste Mgmt. } \\
\text { Section for more information. }\end{array}$ \\
\hline Georgia & Federal Guidelines: See Alabama \\
\hline Hawaii & Very Similar to Federal Guidelines. See Alabama \\
\hline Idaho & Federal Guidelines: See Alabama \\
\hline Illinois & $\begin{array}{l}\text { Used oil filters that are drained and crushed are shipped to a } \\
\text { recycling facility would be considered scrap metal, not waste. } \\
\text { Uncrushed and undrained oil filters are managed as a special } \\
\text { waste. See IL Environmental Protection Agency for more } \\
\text { information. }\end{array}$ \\
\hline Indiana & Federal Guidelines: See Alabama \\
\hline Iowa & Federal Guidelines: See Alabama \\
\hline Kansas & Federal Guidelines: See Alabama \\
\hline Kentucky & Very Similar to Federal Guidelines. See Alabama \\
\hline Louisiana & Federal Guidelines: See Alabama \\
\hline
\end{tabular}




\begin{tabular}{|c|c|}
\hline Maine & Federal Guidelines: See Alabama \\
\hline Maryland & Federal Guidelines: See Alabama \\
\hline Massachusetts & Very Similar to Federal Guidelines: See Alabama \\
\hline Michigan & Very Similar to Federal Guidelines: See Alabama \\
\hline Minnesota & $\begin{array}{l}\text { Used oil filters are prohibited from solid waste disposal. } \\
\text { Minnesota requires business generators of used oil filters to either: } \\
\text { 1. recycle the used oil filter; or } \\
\text { 2. dispose of the filter as hazardous waste } \\
\text { Contact MN Pollution Control Agency, Policy and Planning Div. } \\
\text { for more information. }\end{array}$ \\
\hline Mississippi & Federal Guidelines: See Alabama \\
\hline Missouri & $\begin{array}{l}\text { Similar to Federal Guidelines: See Alabama. The Department } \\
\text { does not require used oil generators to distinguish between terne- } \\
\text { plated and non-terne plated oil filters. }\end{array}$ \\
\hline Montana & Similar to Federal Guidelines. Contact Air \& Waste Mgmt. Bureau \\
\hline Nebraska & Federal Guidelines: See Alabama \\
\hline Nevada & Federal Guidelines: See Alabama \\
\hline New Hampshire & Federal Guidelines: See Alabama \\
\hline New Jersey & Federal Guidelines: See Alabama \\
\hline New Mexico & Federal Guidelines: See Alabama \\
\hline New York & Federal Guidelines: See Alabama \\
\hline North Carolina & Federal Guidelines: See Alabama \\
\hline North Dakota & Federal Guidelines: See Alabama \\
\hline Ohio & Federal Guidelines: See Alabama \\
\hline Oklahoma & Federal Guidelines: See Alabama \\
\hline Oregon & Federal Guidelines: See Alabama \\
\hline Pennsylvania & Federal Guidelines: See Alabama \\
\hline Puerto Rico & Federal Guidelines: See Alabama \\
\hline Rhode Island & $\begin{array}{l}\text { Rhode Island regulates oil filters generated by corporate entities as } \\
\text { hazardous waste. Used oil filters, exclusive of satellite storage, } \\
\text { may not be stored on-site for more than } 90 \text { days. Filters may not } \\
\text { be land filled in Rhode Island. See Dept. Env. Mgmt., Compliance } \\
\text { / Inspection Div. }\end{array}$ \\
\hline South Carolina & Federal Guidelines: See Alabama \\
\hline South Dakota & $\begin{array}{l}\text { Similar to Federal Guidelines. Contact SCDHEC, Bureau of Land } \\
\& \text { Waste Mgmt. Division of Mining \& Solid Waste Mgmt. }\end{array}$ \\
\hline Tennessee & $\begin{array}{l}\text { Similar to Federal Guidelines. Contact TN Department of } \\
\text { Environmental Conservation, Solid Waste Assistance }\end{array}$ \\
\hline Texas & $\begin{array}{l}\text { The Texas rule provides cradle to grave management for used oil } \\
\text { filters. Used oil filters are banned from Texas landfills. The } \\
\text { generator must remove all free-flowing oil from the filters and } \\
\text { make arrangements for filter removal and processing. See } \\
\text { TNRCC, Waste Permits Div., I\&HW Permits, Used Oil Recycling } \\
\text { Program }\end{array}$ \\
\hline Utah & Federal Guidelines: See Alabama \\
\hline
\end{tabular}




\begin{tabular}{|l|l|}
\hline Vermont & Similar to Federal Guidelines: See Alabama \\
\hline Virginia & Federal Guidelines: See Alabama \\
\hline Washington & Federal Guidelines: See Alabama \\
\hline West Virginia & Federal Guidelines: See Alabama \\
\hline Wisconsin & Similar to Federal Guidelines: See Alabama \\
\hline Wyoming & Similar to Federal Guidelines: See Alabama \\
\hline
\end{tabular}

\section{Appendix 4: Flash Calculation}

Let $L$ equal the moles of liquid with mole fractions $\left\{x_{i}\right\}$, and let $V$ be the moles of vapor with mole fractions $\left\{y_{i}\right\}$. The material balance equations are written as

$$
\begin{aligned}
& L+V=1 \\
& z_{i}=x_{i} L+y_{i} V \quad(i=1,2, \ldots, N)
\end{aligned}
$$

where $\left\{z_{i}\right\}$ are the overall mole fractions. Eliminating $L$ from the equations, we get

$$
z_{i}=x_{i}(1-V)+y_{i} V \quad(i=1,2, \ldots, N) \quad \text { Eq. } 1
$$

Raoult's law for vapor-liquid equilibrium is given by

$$
y_{i}=K_{i} x_{i}
$$

where $\mathrm{K}_{i}$ is the "K-value" and is given here by

$$
K_{i}=P_{i}^{s a t} / P
$$

$\mathrm{P}^{\text {sat }}$ is calculated using the Antoine Equation given by

$$
\log _{10} P^{s a t}=A-\frac{B}{T+C}
$$

Eq. 2

Substituting $x_{i}=y_{i} / K_{i}$ in Eq. 1 and solving for $y_{i}$ gives

$$
y_{i}=\frac{z_{i} K_{i}}{1+V\left(K_{i}-1\right)} \quad(i=1,2, \ldots, N)
$$

Eq. 3

since $\sum y_{i}=1$, the sum of Eq. 2 gives

$$
\sum_{i} \frac{z_{i} K_{i}}{1+V\left(K_{i}-1\right)}=1
$$

Since $T, P$, and $\left\{z_{i}\right\}$ are known, the only unknown in Eq. 3 is $V$. The solution is obtained iteratively.

In order to determine if it is possible to do a flash calculation, first perform a bubble pressure, $P_{b}$, and dew pressure calculation, $P_{d}$. The bubble pressure is the pressure where the mixture will start to boil and the dew pressure is the pressure where the mixture will start to condense at a particular temperature. In order to do the flash calculation the pressure needs to be between $P_{d}$ and $P_{b}$. $P_{b}$ is calculated using

$$
P_{b}=\sum_{i} x_{i} P_{i}^{\text {sat }}
$$

with $\left\{x_{i}\right\}=\left\{z_{i}\right\}$. Pdis calculated using 


$$
P_{d}=\frac{1}{\sum_{i} y_{i} / P_{i}^{s a t}}
$$

with $\left\{y_{i}\right\}=\left\{z_{i}\right\}$.

\section{Appendix 5: Sample Flash Claculation}

For $\quad \mathrm{T}=750^{\circ} \mathrm{F}=671.9 \mathrm{~K}$

$\mathrm{P}=15.1 \mathrm{psig}=1.92$ bar

First using values of $\mathrm{z}_{\mathrm{i}}$ and $P_{i}^{\text {sat }}$ shown below, the Bubble Pressure of the oil at $750^{\circ} \mathrm{F}$ is calculated:

$$
\begin{aligned}
P_{b} & =\sum_{i} z_{i} P_{i}^{\text {sat }} \\
& =0.19 * 4.337+0.18 * 2.772+0.19 * 2.105+0.18 * 0.980+0.19 * 1.043+0.07 * 1.071 \\
& =2.17 \mathrm{bar}
\end{aligned}
$$

The Dew Pressure for the oil is also calculated:

$$
\begin{aligned}
P_{d} & =\frac{1}{\sum_{i} y_{i} / P_{i}^{\text {sat }}} \\
& =\frac{1}{0.19 / 4.337+0.18 / 2.772+0.19 / 2.105+0.18 / 0.980+0.19 / 1.043+0.07 / 1.071} \\
& =1.59 \mathrm{bar}
\end{aligned}
$$

Since the pressure, $\mathrm{P}=1.92 \mathrm{bar}$, is between the bubble pressure and the dew pressure, the flash calculation can be performed. If the pressure was greater than the bubble pressure than the mixture would be all vapor and if the pressure was less than the dew pressure, the mixture would be all liquid.

\begin{tabular}{|l|c|c|c|c|c|}
\hline $\begin{array}{c}i \\
\text { Component }\end{array}$ & $\begin{array}{c}z_{i} \\
\text { (overall } \\
\text { composition, } \\
\text { arbitrarily } \\
\text { set) }\end{array}$ & $\begin{array}{c}P_{i}^{\text {sat }}{ }^{\text {(bar) }} \\
P^{\text {sat }}=1{ }^{A-\frac{B}{T+C}} \\
\text { (T in Kelvin) }\end{array}$ & $\begin{array}{c}K_{i}=P_{i}^{\text {sat }} / P \\
\text { (vapor } \\
\text { composition) } \\
y_{i}=\frac{z_{i} K_{i}}{1+V\left(K_{i}-1\right)}\end{array}$ & $\begin{array}{c}\mathrm{X}_{\mathrm{i}} \\
\text { (liquid } \\
\text { composition) } \\
x_{i}=\frac{y_{i}}{K_{i}}\end{array}$ \\
\hline $\mathrm{C}_{18} \mathrm{H}_{38}$ & 0.19 & 4.337 & 2.256 & 0.1902 & 0.0843 \\
\hline $\mathrm{C}_{21} \mathrm{H}_{44}$ & 0.18 & 2.772 & 1.442 & 0.1801 & 0.1249 \\
\hline $\mathrm{C}_{23} \mathrm{H}_{48}$ & 0.19 & 2.105 & 1.095 & 0.1900 & 0.1736 \\
\hline $\mathrm{C}_{26} \mathrm{H}_{54}$ & 0.18 & 0.980 & 0.510 & 0.1797 & 0.3525 \\
\hline $\mathrm{C}_{27} \mathrm{H}_{56}$ & 0.19 & 1.043 & 0.543 & 0.1897 & 0.3496 \\
\hline pyrene & 0.07 & 1.071 & 0.557 & 0.0699 & 0.1254 \\
\hline
\end{tabular}

The value of $V$, the fraction of the mixture that is vaporized, is obtained iteratively by using the MS Excel "Goal Seek" function to change $V$ in order to set 
$\sum_{i} y_{i}=1$

"Goal Seek" calculated $V$ to be 0.998 so $99.8 \%$ of the oil is vaporized in that section at $750^{\circ} \mathrm{F}$.

\section{Appendix 6: Symbol Table}

\begin{tabular}{|l|l|}
\hline PAH & Polycyclic aromatic hydrocarbon \\
\hline$A, B, C$ & Empirical parameters for the Antoine Equation (Appendix 4, eqn2) \\
\hline$L$ & Moles of liquid \\
\hline$V$ & Moles of vapor \\
\hline$x_{i}$ & Liquid mole fraction for component $i$ \\
\hline$y Y_{i}$ & Vapor mole fraction for component $i$ \\
\hline$Z_{i}$ & Overall mole fraction for component $i$ \\
\hline$P$ & Pressure \\
\hline$P_{i}^{\text {sat }}$ & Saturated pressure for component $i$ \\
\hline$P_{b}$ & Bubble pressure \\
\hline$P_{d}$ & Dew pressure \\
\hline
\end{tabular}

\section{Appendix 7: Typical Aromatic Hydrocarbons}

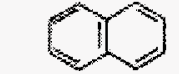

MAPHALNE

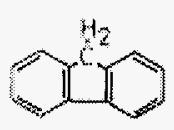

IURENE

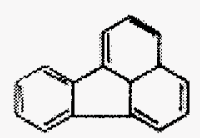

FUO ANTTENE

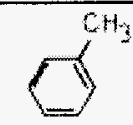

T. $1 \mathrm{kn}$

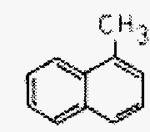

METHVL NAFNHALEW

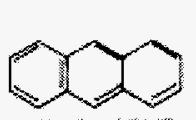

AV HRACNE

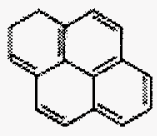

PYAENE

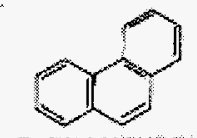

PWWNWHWEN
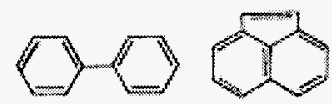

ACENATHFEN

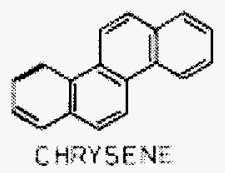

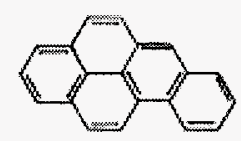

3. 4 BENOPYRE

Figure 7: Some typical aromatics from hydrocarbon pyrolysis.57 Molecules with 2 or more rings are known as polycyclic aromatic hydrocarbons (PAH) 


\subsection{References}

'AISI, "Steel Technology Roadmap”, March 1998, section 2.2.3 AUTOMOTIVE, pg 77.

2 Technical Bulletin, "The Future of Used Oil Filter Recycling in Missouri: An Evaluation of Potential Processes, Product Quality, Recycling Locations, and Economics", February 15, 1997, K.D. Peaslee and D.E. Roberts, II, University of Missouri-Rolla, Department of Metallurgical Engineering.

3 "Report of the Findings on the Waste Classification of Used Automotive Oil Filters", The Convenient Automotive Services Institute, April 1991.

4 "The Process," From "An Introduction to Blast Furnace Technology", ATSI Engineering Services, http://www.steel.org/learning/howmade/blast furnace.htm, 12/17/2001.

5 "AC Delco - Parts Information-Oil Filters-Ultraguard Gold," http://www.acdelco.com/pi filt oil_gold feature.htm, 9/24/01

${ }^{6}$ F.E. Lockwood and R. Dailey, "Lubricant Analysis," Friction, Lubrication and Wear Analysis, 1992, ASM Handbook, Vol. 18, pp. 299-312

7 "Online Sample Report, Oil Sampling Guidelines, " http://www.thetakgroup.com/pennzoilquakerstate/pqs/login.asp, 10/25/01

8 "State Motor Vehicle Registration 1999 Table MV-1,"

http://wwwcf.fhwa.dot.gov/ohim/hs99/tables/mvl.pdf, 10/25/2001

${ }^{9}$ Brent Hazelett, "Private Communications," Oil Filter Manufacturers Council, September 25, 2001.

10 "Recycle Rate for Used Oil Filters." http://www.filltercouncil.org/news/May2000.html, (Filter

Manufacturers Council, FMC PR 01-00, May 4, 2000).

${ }^{11}$ Brent Hazelett, "Private Communications," Oil Filter Manufacturers Council, September 25, 2001.

67 "State Motor Vehicle Registration 1999 Table MV-1,"

http://wwwcf.fhwa.dot.gov/ohim/hs99/tables/mvl.pdf, 10/25/2001

${ }^{12}$ Brent Hazelett, "Private Communications," Oil Filter Manufacturers Council, September 25, 2001.

${ }^{13}$ Nishaj Attassery, "Private Communications," 16 Oct 2001, Email Letter, ArvinMeritor

${ }^{14}$ Ibid

${ }^{15}$ Mike Whitman, "Private Communications," 12 Oct 2001, Fax Memo, Delphi Corporation

${ }^{16}$ Ibid

17 “Tin Plate," http://www.weirton.com/products/tin/tinplate.html, 24 Sep 2001

18 "Weirzin," http://www.weirton.com/products/galv/weirzin.html, 24 Sep 2001

${ }^{19}$ Brent Hazellet, "Private Communications," Oil Filter Manufacturers Council, 18 Oct 2001

${ }^{20}$ Mike Whitman, "Private Communications," 13 Oct 2001, Phone Message, Delphi Corporation

${ }^{21}$ Scott Jacobs, "Private Communications," 24 Oct 2001, Email Letter, Fram Brand, Honeywell Corp.

${ }^{22}$ Nishaj Attassery, "Private Communications," 16 Oct 2001, Email Letter, ArvinMeritor

${ }^{23}$ Edward Adamczyk, "Private Communications," Weirton Steel, Phone Message, 11 Oct 2001.

${ }^{24}$ Ibid

${ }^{25}$ Kent D. Peaslee, "Recycling Used Automotive Filters," Journal of Metals, February, 1994, pg. 46

${ }^{26}$ Harold E. McGannon, ed., The Making Shaping and Treating of Steel, (Pittsburgh: United States Steel, 1971), pg. 456

27 "Engine Oil Filter Study," http://www.scuderiaciriani.com/rx7/oil filter study/, 11 Oct 2001.

${ }^{28}$ Nishaj Attassery, "Private Communications," 16 Oct 2001, Email Letter, ArvinMeritor

${ }^{29}$ Mike Whitman, "Private Communications," 17 Oct 2001, Phone Message, Delphi Corporation

${ }^{30}$ Brent Hazelett, "Private Communications," Oil Filter Manufacturers Council, September 25, 2001.

${ }^{31}$ Ibid.

${ }^{32}$ Kent D. Peaslee, "Recycling Used Automotive Filters," Journal of Metals, February 1994, pg. 44.

${ }^{33}$ Note: Lubricating Oil Specific Gravity can vary from 0.856 to 0.913 . For purposes of this study a value of 0.88 will be used. "Material Data Safety Sheet," Havoline Motor Oil, http://www.equivatexacomsds.com/rd/getsinglemsds.asp?ID=191113, 18 Sep 2001.

${ }^{34}$ Weirton Steel Internet Site

${ }^{35}$ Kent D. Peaslee and Darrell E. Roberts, "Characterization of used automotive oil filters for recycling,"

Resources, Conservation and Recycling 19 (1997), pg 86. 
${ }^{36}$ Santee Cooper Electric Utility, "GOFER, Give Oil For Energy Recovery," http://www.scgofer.org/about.html, November 12, 2001

${ }^{37}$ Wisconsin Energy Bureau. "Paper Pellets for Industrial Fuel," www. wifocusonenergy.com, November 11,2001 .

${ }^{38}$ Bill Vajdek, "Private Communications," American Resource Recovery, Ltd., Maywood, IL, November 15,2001

${ }^{39}$ Tammi Jones, "Private Communications," Commercial Filter Recycling, Los Angeles, California, October 27, 2001.

${ }^{40}$ Gregory C. Potter, "Private Communications," Oil Filter Recyclers, Inc. Easton, IL, November 13, 2001.

${ }^{41}$ Jim Nickerson, "Private Communications," Nickro Recycling Inc., Pittsburg, TX, November 13, 2001.

${ }^{42}$ Terry Jones, "Private Communications," Bernell Recycling, Ranch Cucamonga, CA, November 14, 2001.

${ }^{43}$ Brent Hazelett, "Private Communications," Oil Filter Manufacturers Council November 9, 2001.

44 "Disposal of Terne-Plated and Non Terne-Plated Oil Filters," http://chppm-

www.apgea.army.mil/hwmp/Factsheets/OilFilters.html, January, 2001.

45 "Used Filter Management Regulations," Oil Filter Manufacturers Council, http://filtercouncil.org/regs/

46 "Blast Furnace Roundup," Iron and Steelmaker, Vol. 28, No. 8, August 2001, pp. 75-77.

${ }^{47}$ D. Wakelin, "The Making, Shaping, and Treating of Steel “, $11^{\text {th }}$ Edition, Ironmaking Volume, p751, AISE Steel Foundation, 1999.

${ }_{48}$ Assumed $0.030 \% \mathrm{Sn}$ in melted steel components, which exhibited a $76 \%$ metallic yield.

49 Assumed $0.030 \% \mathrm{Sn}$ in melted steel components, which exhibited a $76 \%$ metallic yield.

${ }^{50} \mathrm{R}$. Jeschar, A Theoretical Model Coupling Kinetics of Ore Reduction and Coke Gasification in Cocurrent and Countercurrent Reactors, Fifth International Iron and Steel Congress, Washington, April 6-9, p 992, Iron \& Steel Society, 1986.

${ }^{51}$ A. Poos, and N. Pongjis, 1994 Turkdogan Symposium Proceedings, Application of Process Models for the design of an Optimized Blast Furnace Process, p 45, Iron \& Steel Society, 1994.

${ }^{52}$ Robert A. Meyers. Environmental Analysis and Remediation, v. 6. John Wiley \& Sons, New York, 1998. p. 3669

${ }^{53}$ Internet

${ }^{54}$ Irwin, Roy J. et al. Environmental Contaminants Encyclopedia, Used Motor Oil Entry. National Park Service, 1997. http://nature.nps.gov/toxic/oilused.pdf.

${ }^{55}$ D.J. Graziano and E.J. Daniels, Assessment of Opportunities to Increase the Recovery and Recycling Rates of Waste Oils. Energy Systems Division Argonne National Laboratory, Contract W-31-109-Eng-38, for the United States Department of Energy, pg 54, August 1995.

56 "NIST Chemistry Web Book", "http://WebBook.nist.gov/cgi/cbook.cgi?ID=C593453\&Units=SI\&Mask=4.".

${ }^{57}$ J.M. Smith and H.C. Van Ness. "Introduction to Chemical Engineering Thermodynamics". McGraw-Hill, Inc. New York, 1987.

${ }^{58}$ James Speight. The Chemistry and Technology of Petroleum $3^{\text {rl }}$ ed. Marcel Dekker, Inc., New York, 1999.

${ }^{59}$ Lyle F. Albright, et al. Pyrolysis: Theory and Industrial Practice. Academic Press, New York, 1983. Iron can act as a catalyst to produce surface carbon. ${ }^{6}$

${ }^{60}$ Nowak et al. Chem Tech. v. 31 p. 496-500, 1979.

${ }^{61}$ G.F. Froment, Coke formation in the thermal cracking of hydrocarbons. Reviews in Chemical Engineering. V. 6, n4, p293-328, 1990.

${ }^{62}$ From: D. H. Wakelin, Blast Furnace Material and Energy Balance. The Making, Shaping and Treating of Steel, $11^{\text {th }}$ Edition, Ironmaking Volume, p734, sec 10.3.5, 1999.

${ }^{63}$ As calculated by the writer.

${ }^{64}$ Recycling Oil and Fuel Filters, www.nycwasteless.com/citysense/initiaves/dosfilters.htm, 2000.

${ }^{65}$ D.A. Kercsmar, et al., Sustained Production in Excess of 9 Tons Per Day/100 fi ${ }^{3}$ WV at Middletown's No. 3 Blast Furnace, Iron \& Steelmaker, p 33, July 1994.

${ }^{66}$ K.D. Peaslee \& D.E. Roberts, II, “ The Future of Used Oil Filter Recycling in Missouri: An Evaluation of Potential Processes, Product, Quality, Recycling Locations, \& Economics", Missouri Department of Natural Resources, p 19, February 15, 1997. 


\subsection{Resumes}

Gregory L. Dressel, P. Eng.

768 Country Club Drive

Pawleys Island, SC 29585 USA

$\begin{array}{ll}\text { Phone } & +1843-237-8337 \\ \text { Fax } & +1843-237-8337\end{array}$

gregdressel@worldnet.att.net

Summary:

Manager and engineer operating a variety of steel melt shops. Well experienced in the management and startup of melt shops using scrap, hot metal and DRI cast into slabs, thin slabs, billets, blooms and beam blanks.

\section{University Level Education:}

1977 B.S. The Pennsylvania State University, University Park, PA, USA. Metallurgical Engineering. 1991 MS The University of Massachusetts, Amherst, MA, USA. Engineering Management

\section{Current Employment:}

1994 to 2000: Dressel Technologies, Independent Consulting and Management Assignments

\begin{tabular}{|c|c|c|c|}
\hline Year & Client & Location & Job Description \\
\hline 2001 & Secret Client (2) & USA & Steelmaking Operations Work \\
\hline $2000-2001$ & SMS DEMAG, Pittsburgh, PA & USA & $\begin{array}{l}\text { Commissioning Consultant in } \\
\text { Start Up of Stainless Melt Shop }\end{array}$ \\
\hline 2000 & Secret Client (1) & USA & Steelmaking Operations Work \\
\hline 2000 & $\begin{array}{l}\text { The Recovery Group, Boston, } \\
\text { MA }\end{array}$ & Hunedoara, Romania & $\begin{array}{l}\text { Operational Assessment of } \\
\text { State Owned Steel Plant }\end{array}$ \\
\hline 2000 & $\begin{array}{l}\text { Concast Standard, Wettingen } \\
\text { Switzerland }\end{array}$ & $\begin{array}{l}\text { Abu Zaabal Military Factory } \\
\text { Cairo, Egypt }\end{array}$ & $\begin{array}{l}\text { AC EAF and Melt Shop } \\
\text { Management and Startup }\end{array}$ \\
\hline 1999-2001 & Iron and Steel Society & Iron and Steelmaker Magazine & $\begin{array}{l}\text { Writer and Coordinator of Skull } \\
\text { Session, Monthly Q \& A } \\
\text { Column }\end{array}$ \\
\hline 1999 & $\begin{array}{l}\text { Pyromet, Johannesburg, } \\
\text { Republic of South Africa }\end{array}$ & USA & $\begin{array}{l}\text { DRI Use in Submerged Arc } \\
\text { Furnace Process Engineering }\end{array}$ \\
\hline 1999 & $\begin{array}{l}\text { Concast Standard, Wettingen } \\
\text { Switzerland }\end{array}$ & $\begin{array}{l}\text { Charter Steel, Saukeville, WI } \\
\text { USA }\end{array}$ & $\begin{array}{l}\text { DC EAF Operations and } \\
\text { Process Improvements }\end{array}$ \\
\hline 1999 & $\begin{array}{l}\text { Concast Standard, Wettingen } \\
\text { Switzerland }\end{array}$ & $\begin{array}{l}\text { Namheng Steel, Lop Buri } \\
\text { Thailand }\end{array}$ & Melt Shop Problem Solving \\
\hline 1999 & $\begin{array}{l}\text { EMC International, Inc } \\
\text { Pittsburgh, PA }\end{array}$ & $\begin{array}{l}\text { SIDERPERU, Chimbote, } \\
\text { Peru }\end{array}$ & $\begin{array}{l}\text { Ladle Furnace Startup and } \\
\text { Management Support. BOF melt } \\
\text { support }\end{array}$ \\
\hline 1998-1999 & Iron and Steel Society & Iron and Steelmaking Magazine & $\begin{array}{l}\text { Wrote and published series } \\
\text { titled, "Use of Direct Reduced } \\
\text { Iron in Electric Arc Furnaces" }\end{array}$ \\
\hline 1998 & DAl Management Assoc. Inc & $\begin{array}{l}\text { AllMet Direct Reduced Iron } \\
\text { Facility, Blytheville, AR }\end{array}$ & $\begin{array}{l}\text { Project work on EAF Dust } \\
\text { recycling facility }\end{array}$ \\
\hline 1998 & $\begin{array}{l}\text { Concast Standard, Wettingen } \\
\text { Switzerland }\end{array}$ & $\begin{array}{l}\text { Guangzhou Iron and Steel } \\
\text { China }\end{array}$ & $\begin{array}{l}\text { Technical and operational } \\
\text { supervision of a DC EAF in } \\
\text { startup phase }\end{array}$ \\
\hline
\end{tabular}




\begin{tabular}{|c|c|c|c|}
\hline Year & Client & Location & Job Description \\
\hline 1998 & $\begin{array}{l}\text { Kvaerner Metals Clecim } \\
\text { Saint Chamond, France }\end{array}$ & $\begin{array}{l}\text { Tung Ho Steel } \\
\text { Miaoli, Taiwan, R.O.C }\end{array}$ & $\begin{array}{l}\text { Ladle Furnace Operations and } \\
\text { Metallurgy Improvements }\end{array}$ \\
\hline $1997-1998$ & $\begin{array}{l}\text { Concast Standard, Zurich } \\
\text { Switzerland }\end{array}$ & $\begin{array}{l}\text { Southern Steel Berhad, Penang, } \\
\text { Malaysia }\end{array}$ & $\begin{array}{l}\text { Technical and operational } \\
\text { supervision of a twin shell DC } \\
\text { EAF and AC Ladle Furnace in } \\
\text { startup phase }\end{array}$ \\
\hline 1997 & $\begin{array}{l}\text { Kvaerner Metals, Pittsburgh, PA, } \\
\text { USA }\end{array}$ & $\begin{array}{l}\text { Wheeling Pittsburgh Steel, } \\
\text { Steubenville, OH, USA }\end{array}$ & $\begin{array}{l}\text { Process engineering and operator } \\
\text { training on a CAS OB ladle } \\
\text { metallugy unit }\end{array}$ \\
\hline 1997 & $\begin{array}{l}\text { Concast Standard, Zurich, } \\
\text { Switzerland }\end{array}$ & Daye Steel, Huangshi, China & $\begin{array}{l}\text { Technical and operational } \\
\text { supervision of a DC EAF in startup } \\
\text { phase }\end{array}$ \\
\hline $1996-1997$ & Namheng Steel, Lopburi, Thailand & Namheng Steel, Lopburi, Thailand & $\begin{array}{l}\text { Management of a DC EAF, AC LF } \\
\text { and billet melt shop in start up } \\
\text { phase }\end{array}$ \\
\hline 1996 & Gallatin Steel, Ghent, KY USA & Gallatin Steel, Ghent, KY USA & $\begin{array}{l}\text { EAF operational training in shop } \\
\text { using DC EAF and Thin Slab } \\
\text { Caster }\end{array}$ \\
\hline 1996 & $\begin{array}{l}\text { Kvaerner Metals, St. Chamond, } \\
\text { France }\end{array}$ & Essar Steel, Surat, India & $\begin{array}{l}\text { Performance testing of a DC EAF } \\
\text { using } 80 \% \mathrm{HBI} \text { as a raw material. } \\
\text { SPC training }\end{array}$ \\
\hline 1996 & $\begin{array}{l}\text { Kvaerner Metals, Sheffield, } \\
\text { England }\end{array}$ & Hadeed, Saudi Arabia & $\begin{array}{l}\text { Engineering Calculations for DRI } \\
\text { feed rates and EAF Practices }\end{array}$ \\
\hline 1996 & $\begin{array}{l}\text { Dressel Technologies, Pawleys } \\
\text { Island, SC, USA }\end{array}$ & $\begin{array}{l}\text { AISE Automation Conference, } \\
\text { Nashville, TN, USA }\end{array}$ & $\begin{array}{l}\text { Presentation of a paper on melt } \\
\text { shop simulation }\end{array}$ \\
\hline $1995-1996$ & $\begin{array}{l}\text { ABB Industrie, AG, Baden, } \\
\text { Switzerland }\end{array}$ & $\begin{array}{l}\text { Shanghai No. } 3 \text { Steel Works, } \\
\text { Shanghai, China }\end{array}$ & $\begin{array}{l}\text { Technical and operational } \\
\text { supervision of two DC EAF's in } \\
\text { startup phase }\end{array}$ \\
\hline $1994-1995$ & $\begin{array}{l}\text { Kvaerner Metals, Pittsburgh, PA, } \\
\text { USA }\end{array}$ & Essar Steel, Surat, India & $\begin{array}{l}\text { Management of two DC EAF's } \\
\text { and AC Ladle Furnaces in startup } \\
\text { phase using } 80 \% \text { HBI }\end{array}$ \\
\hline 1994-1995 & $\begin{array}{l}\text { Caribbean Ispat Limited, Trindad } \\
\text { and Tobago, West Indies }\end{array}$ & $\begin{array}{l}\text { Caribbean Ispat Limited, Trindad } \\
\text { and Tobago, West Indies }\end{array}$ & $\begin{array}{l}\text { Steelmaking and SPC Training and } \\
\text { Quality Consulting in EAF shop } \\
\text { using } 90 \% \text { DRI }\end{array}$ \\
\hline 1994 & $\begin{array}{l}\text { Van Deilen Industries, } \\
\text { Lambertville, MI, USA }\end{array}$ & $\begin{array}{l}\text { Van Deilen Industries, } \\
\text { Lambertville, MI, USA }\end{array}$ & $\begin{array}{l}\text { Conceptual engineering for a micro } \\
\text { steel plant }\end{array}$ \\
\hline 1994 & $\begin{array}{l}\text { Dressel Technologies, } \\
\text { Pawleys Island, SC, USA }\end{array}$ & $\begin{array}{l}\text { Dressel Technologies, } \\
\text { Pawleys Island, SC, USA }\end{array}$ & $\begin{array}{l}\text { Established Dressel Technologies } \\
\text { as a metallurgical and steel plant } \\
\text { management consulting firm }\end{array}$ \\
\hline
\end{tabular}

\section{Former Employers:}

1993 to 1994 Florida Steel, Jacksonville, Fl, USA Melt shop process engineer

1987 to 1993 Georgetown Steel, Georgetown, SC, USA. Management of billet caster process engineering and quality control in a carbon steel melt shop using $50 \%$ direct reduced iron (DRI). Supervision of various operational personnel. Shop produced a large quantity of high carbon wire rod products.

1980 to 1987 National Steel Research Center, Weirton, WV, USA. Technical management of a number of steelmaking and slab continuous casting research projects. Supervision of technical personnel.

1978 to 1980 Weirton Steel, Weirton, WV, USA. Operational management of a vacuum degasser and continuous slab caster operations. Supervision of operational personnel.

\section{Professional License:}

State board certified professional engineer, PA and WV.

\section{References and Publications:}

Available upon request 


\section{JENNIFER H. HILL \\ ⿺辶h7u@andrew.cmu.edu}

\section{Graduate Student}

\section{Campus Address:}

Carnegie Mellon University

Department of Chemical Engineering

5000 Forbes Avenue

Pittsburgh, PA 15213

(412) 268-3039

\section{Home Address:}

105 Heston Drive

Cranberry Township, PA 16066

(724) 772-9018

OBJECTIVE To obtain an industrial position in research and development that uses my engineering skills and knowledge about advanced process control and modeling.

EDUCATION

Carnegie Mellon University, Pittsburgh, PA

Ph.D. Chemical Engineering, Expected March 2002

Thesis: Robust Adaptive Control with Unknown Disturbances.

Advisor: B. Erik Ydstie

GPA: $3.33 / 4.00$

Pennsylvania State University, State College, PA

B. S. Chemical Engineering with Honors, 1997

GPA: $3.89 / 4.00$ Ranking: $2 / 110$

Franklin Regional High School, Murrysville, PA, 1993

\section{EXPERIENCE AND}

QUALIFICATIONS

Ph.D. Research Project:

Carnegie Mellon University
(8/97-Present) Pittsburgh, PA

- Developed feedforward adaptive control algorithm for a Kodak satellite as Ph.D. Qualifier Project.

- Developed a robust adaptive stopping algorithm that prevents parameter drift and bursting.

- Developed an adaptive optimization algorithm for a silicon reactor.

- Experience with adaptive control, identification, dynamic modeling and model predictive control algorithms.

Process Control Research Consultant:

(5/99-1/01) PPG Industries

- Implemented an Extended Horizon Self Tuning Controller for furnace crown temperature control, which improved efficiency of furnace control.

- Developed furnace bottom temperature model and adaptive predictive controller.

- Conducted control experiments to obtain PID tuning parameters for reheat temperature control. 
- Studied effect of shear stress on aortic smooth muscle cells for honors thesis.

- Developed new experimental setup for my project.

\section{Student Engineer:}

Calsicat (Division of Mallinckrodt Chemical)
$(5 / 95$ - 8/95)

Erie, PA

- Tested the activity of experimental catalysts using micro-reactors.

- Analyzed products using gas chromatography, UV spectroscopy, and analytical chemistry

\section{RELATED}

COURSES

Mathematical Techniques in Chemical Engineering Process Systems Engineering and Optimization Computational Methods for Large Scale Processes Linear Systems and Control

Fluid Dynamics

Chemical Plant Design

COMPUTER SKILLS:

Pro IL/Provision, MATLAB, Fortran, C, GAMS, LaTex, Unix, Windows

\section{CONFERENCE PRESENTATIONS:}

- Hill, Jennifer and Erik Ydstie. "Robust Adaptive Control: How to Stop the Estimator to Prevent Bursting". 2001 AIChE Annual Meeting, Reno, NV, November 2001.

- Hill, Jennifer and Erik Ydstie. "Parameter Estimation and Robust Adaptive Control". 2000 AIChE Annual Meeting, Los Angeles, CA, November 2000.

- Hsu, Jennifer and Erik Ydstie. "Robust Adaptive Control with Unknown Disturbances". 1999 AIChE Annual Meeting, Dallas, TX, November 1999.

PUBLICATIONS:

- Hill, Jennifer and Erik Ydsite. "Adaptive Control without Parameter Projection and Unknown Sign of the High Frequency Gain". Submitted to International Journal of Adaptive Control and Signal Processing.

- Hill, Jennifer, Erik Ydstie, and Yu Jiao. "Adaptive Control of an Industrial Float Glass Process". Submitted to IFAC World Congress, 2002.

- Hill, Jennifer, Erik Ydstie, and Yu Jiao. "Adaptive Predictive Control of Glass Temperature". To be submitted to Automatica.

PROFESSIONAL AFFILIATIONS: American Institute of Chemical Engineers (AIChE)

AWARDS:

- Carnegie Mellon University Graduate Fellowship (1997-2002)

- Penn State Engineering Society Scholarship (1993-1997)

- Penn State Academic Excellence Scholarship (1993-1997)

- Graduated Penn State University with Highest Distinction (1997)

REFERENCES: Available on Request 


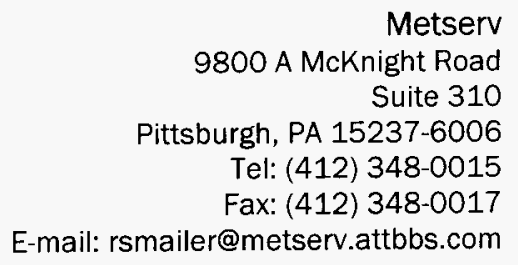

NAME Smailer, Ralph M

CITIZENSHIP United States of America

PROFESSIONAL EXPERIENCE

1999 to Present $\quad$ Director, Metallurgical Services - METSERV

Provides consulting services related to Conceptual Engineering of EAF Steelplants, Steelplant Feasibility and Modernization Studies, Process Simulation and Logistics Studies, Direct Reduction (of iron ore) Process Plant Studies, the marketing of Hot Briquetted Iron (HBI) to the steel industry, technology assessment of Pressurized Fluid Bed Combustion (PBFC) of carbonacaeous materials for power generation, and as a manufactures representative of Industrial Fans and Dust Collection Baghouses.

$1980-1998$

Vice President, Process Technology - Kvaerner Metals Responsible for the technical management of many projects, including RH vacuum degassing, ladle metallurgy, HYL III direct reduction process plants, iron ore pellet plants, steel strip processing lines, steelmaking feasibility studies, and other projects relating to mineral processing, iron and steelmaking, industrial furnaces and chemical industry process plants. He has also been actively involved in technology assessment and acquisition, and has served as Patent Administrator for the Pittsburgh office.

Also responsible for technology assessment, development and acquisition of new technology and enhancement of existing technologies in the fields of mineral processing, iron and steelmaking, industrial furnaces, and chemical engineering. Duties include coordination with worldwide Kvaerner Metals offices, licensees; technical collaboration with other companies; management of Process Technology Department having a senior technical staff to provide sales support, proposals, process engineering, hot commissioning, and satisfaction of performance guarantees on proposals and/or contracts; and administration of patent and licensing activities. 
General Manager, Process Technology - Kvaerner Metals

Responsible for technical coordination, sales support, process engineering, and commissioning for industrial furnaces in the fields

of aluminum heating and melting, steel heating, and electric arc melting, refining furnaces, and ladle metallurgy facilities. Also directed sales and technology of the Arc Furnace Department.

Manager, Arc Furnaces - Kvaerner Metals

Developed new/enhanced electric arc furnace product line. Duties included updating the design basis to provide an enhanced electric arc furnace design, negotiating license agreement with Daido Steel Company, Tokyo for their Ladle Furnace Process; directing sales and marketing activities to enter market dominated by well known and successful competitors; negotiating supplemental license agreement with NKK Corporation, Tokyo, for their NK-AP Process; receiving acceptance of Japanese technology supply to USA steel plant customers; and winning contracts.

Business Development Specialist - Kvaerner Metals

Responsible for re-introduction of the FIOR (Fluid Bed Iron Ore Reduction) direct reduction process to the worldwide marketplace. Duties included negotiating technical cooperation agreement with FIOR de Venezuela to provide direct reduced iron steelmaking technology to their worldwide customers for the FIOR DRI/HBI product; developing procedures that were adopted by the International Maritime Organization for the code of safe shipment of DRI cargoes worldwide; assisting in the sales and marketing of the proprietary FMC formed cokemaking process; and evaluating several new technologies for potential new product lines.

Also responsible for engineering analysis and development engineering directed to the enhancement of the FIOR process to improve fluid bed processing of iron ore for longer term availability of the process plant between turnarounds.

1964 - $1980 \quad$ Supervisor - Manufacturing Technology - Lukens Steel Company Assigned to direct start-up of \$4 million continuous material handling system for use with direct reduced iron feeding to arc furnaces. Duties included directing operating, maintenance, and technical efforts; obtaining project productivity and cost goals; and developing Closed Loop computer control of electric arc furnace to give desired steel temperature. Also negotiated and controlled purchase of Technical Assistance contract with Daido Steel 
Company Ltd., Japan, and assisted in coordination of training program, and implementation of ultra-rapid-melting practices for the electric arc furnace

Supervisor, Manufacturing Technology - Lukens Steel Company Assigned to a 3-member corporate planning committee, which was responsible for technology in order to obtain a $30 \%$ increase in steelmaking capacity. A resulting $\$ 60$ million, 5-year plan was developed based upon up rating of existing arc furnaces. $\$ 10$ million was appropriated in December, 1977.

\section{Supervisor, Hot Briquetting Facility for Steel Turnings - Lukens} Steel Company

Responsible for developing technical concept for a hot briquetted steel turnings based product with chemical properties engineered for steelmaking. Duties included technical evaluation of 100,000 tons/year facility to make hot briquetted turnings product.

1962 to 1964

Research Engineer, Process, in Electric Furnace Operations - Luken Steel Company

Responsible for steelmaking development activities of 2 electric furnaces at 100 tons and 2 at 150 tons. Duties included development and coordination of major production trials involving the use of directly reduced iron products in electric furnace steelmaking, rapid refining, and low sulfur steel production.

Metallurgical Investigator - LTV Steel Company (J \& L Steel)

Responsible for the installation and start-up of a 400 -ton vacuum degassing facility Duties included assisting in evaluating metallurgical practices. Was also responsible for developing a liquid metal sampling procedures for dissolved gas analysis for an open hearth shop, 400 ton, oxygen blown, hot metal practice.

Metallurgical Investigator, Trainee (in the area of blast furnaces) LTV Steel Company

Responsible for developing computer program for start-up, and burden calculations for raw material feed to blast furnace. 


\section{Technical Publications}

"Modeling for DRI Value in Steelmaking", Smailer R M, Sheftel VM, Holmes R L; Steel Times International, September, 1999

"Modeling for DRI Value in Steelmaking", Smailer R M, Sheftel VM, Holmes R L; Advanced Technology Symposium - Scrap Alternatives ;Iron and Steel Society, Trinidad, West Indies, February 28 - March 3, 1999

"Charge Mix Optimization", Cates L E, Sheftel V M, Smailer R M; 56 ${ }^{\text {th }}$ Electric Furnace Conference, Iron \& Steel Society, New Orleans, LA, November 15 - 18, 1998

"The Evolution of Technical Equipment and Process Development in Support of Electric Furnace Production", Smailer RM; AIME 50th Electric Furnace Conference, Atlanta, Georgia, November, 1992

"The Significance of Electric Furnace Steel in Replacing Traditional Technologies", Smailer RM, Pekor DF, Pittsburgh Coal Conference, October 14-18, 1991

"The Use of Natural Gas in the FIOR Process", Smailer RM, Triplett DW, Gas Research Conference on "Natural Gas Use in the Production of Virgin Iron Units", Chicago, Illinois, April 23, 1987

"FIOR Today - Operations and Products", Whipp, RH, Smailer RM, Kulberg HA, Arab Steel 127, p. 44-72, 1985.

"Development of the NK-AP Ladle Refining Process:, Smailer RM, Ikegami Y, Iron and Steel Engineer, 62 (11), p. 29-33, November 1985

"Phosphorus Control in DRI Steelmaking", Smailer RM, Electric Furnace '83, Mexico City, Mexico, June 12-15, 1983, Instituto Latinoamericano del Fierro y El Acero, 1983

"Hot Briquetting of FIOR Fines", Smailer RM, Whipp RH, Kuby OA, Malakouti N SME-AIME Fall Meeting and Exhibit, Society of Mining Engineers of AIME, 1981

"FIOR - 300,000 Tons by Water", Molina MA, Smailer RM, Direct Reduction '80 Conference, July 27-30, 1980, Instituto Latinoamericana del Fierro y El Acero, 1980

"Handling Storage, and Shipment of Direct Reduced Iron", Jensen HB, Smailer RM, $39^{\text {th }}$ Ironmaking Conference, Iron and Steel Society of AIME, Warrendale, Pennsylvania, p. $430-436,1980$

"Transportation and Storage of Direct Reduced Iron", Smailer RM, Jensen HB, (Chapter for AIME book on Direct Reduction of Iron, 1980) 
"Practical Aspects of Electroslag Re-melting Technology", Mitchell A, Smailer RM, International Metals Reviews, v4, n5-6, p. 231-264

"Utilization of Direct Reduction Iron in Electric Steelmaking", Smailer RM, Jensen HB, Scott WW, Jr., Electric Furnace Conference Proceedings, Volume 32, p. 29-36, 1975

"Utilization of Direct Reduction Iron in Electric Steelmaking", AISE Annual Meeting, New York, NY 1974

"Utilization of Direct Reduction Iron in Electric Steelmaking", Smailer RM, Jensen HB, Scott WW, Jr., UNIDO (United Nations Industrial Development Organization) Third Interregional Symposium Iron Steel Industry, Brazil, October 1973

"Operating Benefits of Continuously Charging Pre-reduced Ore Briquettes to a 150-T Electric Furnace", Smailer RM, Price JA, Metallurgical Society AIME, National Open Hearth and Basic Oxygen Steel Conference Proceedings, v53, Detroit Meeting, p 38-43, April 6-8, 1970

"Vacuum Degassing of Specialty Plate Steel", McMichael RC, Smailer RM, Edwards DY, Blast Furnace Steel Plant, March 1969

"Development of Operating and Metallurgical Practice for Lukens 150-Ton Vacuum Degassing Unit", Fogelman EL, Wilt HW, Smailer RM, Journal of Metals v18, n5, p 623-627, May 1966

Book: Direct Reduced Iron: Technology and Economics of Production and Use, Stephenson, Robert H; Smailer, Ralph M., Iron and Steel Society AIME, Warrendale, Pennsylvania, 1980

\section{Patents:}

Steelmaking"

Patent No. 3,809,986, "Combination Iron and Iron Oxide Briquetting for Honors and Awards:

McFarland Award for Achievement in Metallurgy, Penn State Chapter, ASM International, 1993

Centennial Fellow, College of Earth and mineral Science, Pennsylvania State University, 1996 